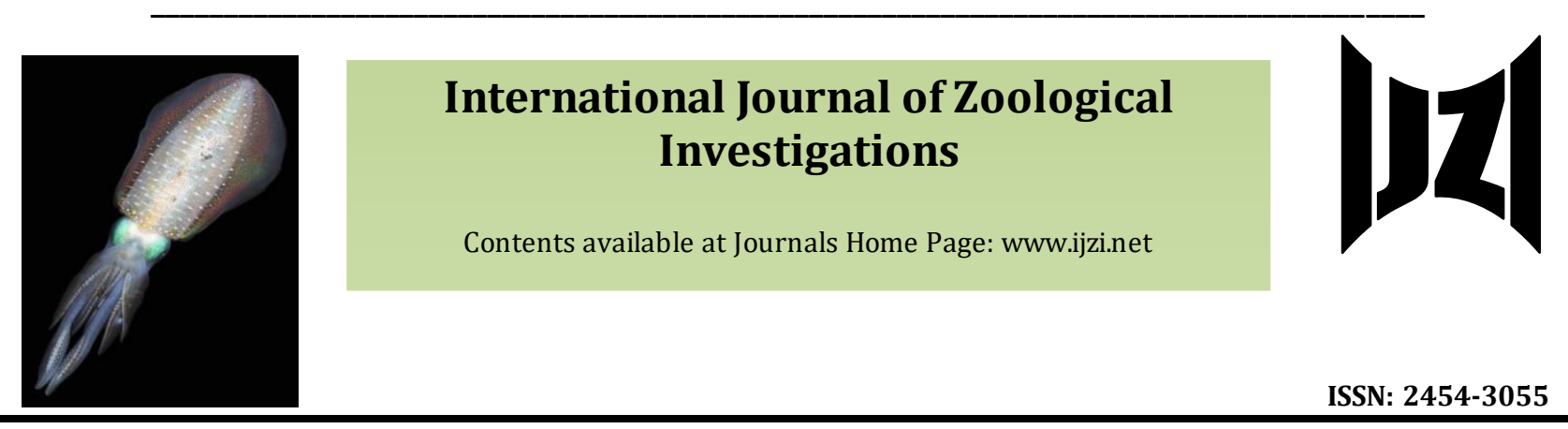

\title{
Faunal Biodiversity of Lycosidae (Araneomorphae: Araneae: Arachnida) in India: An Updated Checklist
}

\author{
Singh Rajendra \\ Department of Zoology, Deen Dayal Upadhyaya Gorakhpur University, Gorakhpur 273 009, India
}

Received: 22 $2^{\text {nd }}$ March, 2021

Accepted: $2^{\text {nd }}$ April,, 2021

Published online: $4^{\text {th }}$ April, 2021

https://doi.org/10.33745/ijzi.2021.v07i01.011

\begin{abstract}
Faunal biodiversity of the wolf spiders (Lycosidae: Araneomorphae: Araneae: Arachnida) in different states of India and union territories is presented herewith. A total of 155 species placed under 25 genera of Lycosidae were recorded in all states and union territories of India except Nagaland, Daman and Diu and Dadra and Nagar Haveli, and Lakshdweep, out of which 91 species (58.7\%) were strictly endemic. However, among them 8 species seem to be erroneous report or misidentification. Maximum number of species were recorded in Maharashtra followed by 65 species in West Bengal, 57 species in Gujarat, 50 species in Uttarakhand, 39 species in Madhya Pradesh, 38 species in Kerala, 36 species in Karnataka, 33 species in Jammu and Kashmir and less than 30 species are recorded in other states. Six species of Lycosidae are widely distributed, viz. Wadicosa fidelis (O. Pickard-Cambridge, 1872) (25 states, 3 union territories), Pardosa sumatrana (Thorell, 1890) (23 states, 1 union territory), Pardosa pseudoannulata (Bösenberg and Strand, 1906) (19 states, 1 union territory), Hippasa agelenoides (Simon, 1884) (17 states, 1 union territory), Hippasa greenalliae (Blackwall, 1867) (16 states, 1 union territory), and Lycosa tista Tikader, 1970 (16 states). About one-third of the species of Lycosidae reported in India are recorded only in one state or from the type locality. Hence, extensive faunistic surveys for these spiders are required.
\end{abstract}

Keywords: Lycosidae, Checklist, Faunal distribution, Wolf spiders, India

Citation: Singh Rajendra: Faunal biodiversity of Lycosidae (Araneomorphae: Araneae: Arachnida) in India: An updated checklist. Intern. J. Zool. Invest. 7 (1): 110-158, 2021.

https://doi.org/10.33745/ijzi.2021.v07i01.011

\section{Introduction}

The spiders are the common name of the arachnids that belong to the order Araneae (Arthropoda: Chelicerata: Arachnida) and are among the most common and abundant entomophagous creatures in the terrestrial ecosystems throughout the world. They are known to possess a very diverse range of lifestyles and foraging behaviours 
(Nyffeler and Birkhofer, 2017). The spider community not only consumes approximately 400-800 million tons of prey (mostly insects) globally per year but also serve as a food source for an extremely diverse predatorsparasitoids-parasites complex, birds, amphibians, lizards, snakes, shrews, mice, bats, fish etc. (Nyffeler and Birkhofer, 2017). At present, spiders consist of 49,243 species placed in 4,209 genera belonging to 128 families (WSC, 2021). Also, there are several species in the wild and museums that still await description and classification. It is estimated that about $70-80 \%$ of the species have yet to be described. Despite recent researches on the faunistic biodiversity surveys of spiders in India, their number is not enough as compared to other parts of the world. For example, Canada has a cold climate and has relatively limited biodiversity, yet 1,477 species of spiders belonging to 45 families are recorded (Bennett et al., 2019) while India has a very rich biodiversity, a tropical climate with biodiversity hotspots, and the manpower to conduct biodiversity surveys, but the best account so far lists only 1,859 species belonging to 477 genera (Caleb and Sankaran, 2021). Recently, the species distribution and checklist of 55 families of spiders have been updated in India (Sharma et al., 2020 a, b, 2021; Singh BB et al., 2020, 2021; Singh, 2021 a, b; Singh and Singh, 2020, 2021; Singh et al., 2020 a, b, c, d, e, f, $2021 \mathrm{a}, \mathrm{b}$; Tiwari and Singh, 2021; Tiwari et al., $2021 \mathrm{a}, \mathrm{b}$ ).

Lycosidae is one of the families of araneomorph and ecribellate spiders that commonly called wolf spiders. These spiders are 3-45 mm long, robust, agile, cryptically coloured in shades of brown, gray to almost black, depending on their surroundings. All legs are spinose and provided with 3 tarsal claws, usually with scopulae for adhesion. The abdomen is oval and always covered with dense hairs. The wolf spiders resemble nursery web spiders (family Pisauridae) but differ particularly in eye pattern and the fate of egg sacs. The eight eyes of wolf spiders are all dark in colour and arranged in three rows in a typical style. The anterior row has four small eyes set in a straight or slightly curved row, the second row has two large eyes further up on the vertical front, and the posterior row has two medium-sized eyes on the sides of the head which may be roughly steep-sided; while in nursery web spiders all eyes are of roughly equal size. The female wolf spiders carry their egg sacs attached to their spinnerets, while the nursery web spiders carry their egg sacs with their chelicerae and pedipalps (Tiwari and Singh, 2021). The majority of wolf spiders are diurnal and do not spin webs for capturing prey, but they run about in grass, leaf litter, over sandy or stony areas, across the surface of the water and many other places and hunt the prey actively (Foelix, 2011). Few wolf spiders are often found in man-made constructions. However, some genera, e.g. Aulonia C.L. Koch, 1847, Hippasa Simon, 1885 and Sosippus Simon, 1888 construct sheet webs provided with a funnel retreat; Alopecosa Simon, 1885, Arctosa C.L. Koch, 1847 and Trochosa C.L. Koch, 1847, make burrows in the ground lined with silk that serves as retreats and a place for the females to guard their egg sacks; Pirata Sundevall, 1833 build silk tubes in vegetation where they rest for a while; and Adelocosa Gertsch, 1973, live in a cave and are blind unlike most of the wolf spiders, and female carries the egg sac in her mouthparts until the spiderlings hatch. Female wolf spiders are 
usually monogynous and devour the next males that attempt to mate her (Wilder and Rypstra, 2008). Among the spiders, wolf spiders are unique in the maternal care of spiderlings. After emergence from the egg sac, these spiderlings mount on the legs of the mother and take position onto the dorsum of her abdomen. The mother carries these spiderlings for several days or even weeks until they are ready to disperse. Morphological, phylogenetic and behavioural relationships between the species of Lycosidae are well illustrated by Rovner (1980), Zehethofer and Sturmbauer (1998), Murphy et al. (2006), Marshall and Martin (2011) and Planas et al. (2013).

Spiders are mostly entomophagous and are among the most abundant biocontrol/natural agents in many agroecosystems, still their role in biological control programme is still disputed because they not only consume pest populations but also other biocontrol agents (predators/ parasitoids) and thus may hamper the biocontrol programme of the pests caused by those bioagents (Singh, $2021 \mathrm{a}, \mathrm{b}$ ). However, in irrigated rice at the early crop stages, the natural control of insect population is mainly attributed to spiders and the most abundant spiders assessed across the cropping season are wolf spiders next to long-jawed spiders (Tetragnathidae) (Barrion and Litsinger, 1984; Singh and Singh, 2014; Huang et al., 2018). Despite their role as insect predators and being crucial to the health of terrestrial ecosystems, only 12 species, Adelocosa anops Gertsch, 1973 (endangered, cavernicolous in Hawaii) (World Conservation Monitoring Centre, 1996 a), Dolocosa dolosa (O. PickardCambridge, 1873) (endangered, in St. Helena) (White et al., 2019 a), Hogna cinica (Tongiorgi,
1977) (critically endangered, in St. Helena) (White et al., 2019 b), Hogna inexorabilis (0. Pickard-Cambridge, 1870) (decreasing, in St. Helena) (White et al., 2019 c), Hogna ingens (Blackwall, 1857) (decreasing, in Madeira) (Cardoso, 2014), Hogna ligata (0. PickardCambridge, 1870) (decreasing, in St. Helena) (White et al., 2019 d), Hogna nefasta Tongiorgi, 1977 (decreasing, St. Helena) (White et al., 2019 e), Lycosa elysae Tongiorgi, 1977 (critically endangered, in St. Helena) (White et al., 2019 f), Lycosa ringens Tongiorgi, 1977 (endangered, in St. Helena) (White et al., 2019 g), Pardosa diuturna Fox, 1937 (vulnerable, in Canada, Alaska) (World Conservation Monitoring Centre,1996 b), Sosippus placidus Brady, 1972 (vulnerable, in USA) (World Conservation Monitoring Centre, 1996 c), and Vesubia jugorum (Simon, 1881) (decreasing, in Italy) (Isaia and Mammola, 2018) were listed in IUCN Red List of Threatened Species as either critically endangered, endangered, vulnerable, or decreasing. However, none of the species recorded in India is on this list. Indeed, no attempt was made in this direction even though several species are known only from their type localities.

Information regarding the Indian Lycosidae is insufficient and highly incoherent primarily due to the unexplored diversity of these spiders in several parts of the country like other families of spiders (Sharma et al., 2020 a, b, 2021; Singh BB et al., 2020, 2021; Singh, 2021a, b; Singh and Singh, 2020, 2021; Singh et al., 2020 a, b, c, d, e, f, 2021; Tiwari and Singh, 2021; Tiwari et al., 2021 a, b). There are several species of these spiders yet to be described and several species recorded from India have also been misidentified as they are said to be identified by using existing 
old literatures without a re-examination of the corresponding types and without consulting any spider taxonomist (Singh, 2021 a, b). Hence, these reports need re-examination. At present the faunal survey results of wolf spiders are all scattered in the literature and so far no consolidated account is available regarding their distribution pattern across the country. Therefore, this present report was undertaken to provide an up-to-date checklist of Indian Lycosidae in different states and union territories of India.

\section{Materials and Methods}

This checklist is based on the literature published in recent past books, journals and few authentic theses, websites, and World Species Catalog up to March 20, 2021. Some references of the faunistic surveys were omitted because of repetition. In most of the literature, published earlier, several errors crept in the scientific names of the spiders even in the recent ones. It happened because such contents become outdated quickly and, due to their perceived comprehensiveness, readers sometimes overlook newer sources of data. Additionally, the researches on spider taxonomy are continued with the description of new taxa, their modified status, and the publication of other nomenclatural decisions (Singh, 2021 a, b; Singh and Singh, 2020, 2021; WSC, 2021). If a spider species is identified only up to a generic level, it was considered as species if no other species of that genus is reported within the state. In the present checklist, attempts have been made to correct the errors in the scientific names of the spiders following World Spider Catalog. Only those synonymies were mentioned that were reported in India. All the endemic species are marked with *. Seemingly, misidentified and erroneous records are marked with ?. Only those species were considered endemic that were exclusively found only in India. If the spider species is not endemic, its elsewhere distribution is also provided following the World Spider Catalog (WSC, 2021) and other existing litrature.

\section{Results and Discussion}

In India, Walckenaer (1837) was probably the first who had described a wolf spider, Lycosa indagatrix from Tamil Nadu. Thereafter, Blackwall (1867) described a species, Hippasa greenalliae from western Uttar Pradesh. Later, in 1885, 0. Pickard-Cambridge (1885 a) descrbried three species, Hogna irascibilis, Hogna rubromandibulata and Trochosa propinqua from Leh (Ladakh) and Sind valley (Jammu and Kashmir); and Simon (1885 a) described four species, Crocodilosa leucostigma, Evippa rubiginosa, Lycosa chaperi and Pardosa partita from Karnataka.

In 1891, two more species of wolf spiders were described from Andaman and Nicobar Islands by Thorell (1891), namely Pardosa thalassia (Thorell, 1891) and Draposa nicobarica (Thorell, 1891). In $19^{\text {th }}$ century, three more species were described, namely, Crocodilosa maindroni by Simon (1897) from Maharashtra, Lycosa phipsoni and Lycosa wroughtoni by Pocock (1899) from Maharashtra and Gujarat, respectively. With the beginning of $20^{\text {th }}$ century, Pocock (1901) described seven species, Lycosa fuscana, Lycosa goliathus, Lycosa iranii, Lycosa madani, Lycosa masteri, Lycosa pictula and Lycosa prolific from Maharashtra. After two decades, Gravely (1924) described 16 species and recorded 5 more species of wolf spiders from different states of India. Again, after a decade, Reimoser (1934) described two species 
[Arctosa lesserti Reimoser 1934, Geolycosa carli (Reimoser 1934)] and recorded two more species [Pardosa vagula (Thorell, 1890), Pardosa pusiola (Thorell, 1891)] from Tamil Nadu and Caporiacco (1935) described 7 species (Acantholycosa baltoroi, Pardosa flavisterna, Pardosa hydaspis, Pardosa tridentis, Schizocosa concolor, Evippomma evippiforme, Hippasa flavicoma) and recorded 4 species [Trochosa terricola (Thorell, 1856), Pardosa condolens (0. Pickard-Cambridge, 1885), Pardosa stellata (0. PickardCambridge, 1885), Pardosa vindicata (0. Pickard-Cambridge, 1885)] from Jammu and Kashmir. Among the Indian authors, Sinha (1951) was the first to describe a species of Lycosidae, Arctosa khudiensis (Sinha, 1951) from Bihar. Later on, Sadana (1969), Tikader (1970, $1977 \mathrm{a}, \mathrm{b})$, Tikader and Mukerji (1971), Tikader and Malhotra (1976, 1980), Biswas and Biswas (1992), Patel and Reddy (1993), Saha et al. (1994), Arora and Monga (1994) and Gajbe and Gajbe (1999) described several species of wolf spiders from different states and union territories of India. In the present century, 22 species were described from India, one species from Assam (Ahmed et al., 2014), 2 species from Kerala (Malamel et al., 2015, Kronestedt, 2017), 4 species from West Bengal (Majumder, 2004; Dhali et al., 2012), 6 species from Chhattisgarh (Gajbe, 2004) and 9 species from Madhya Pradesh (Bhandari and Gajbe, 2001; Gajbe UA, 2004; Gajbe PU, 2004).

At present, 155 species belonging to 25 genera were described or recorded from India, out of which, 91 species (58.7\%) were strictly endemic, i.e. recorded only in India. However, the Indian record is only $6.4 \%$ of the world Lycosidae fauna $(2,428$ species placed in 124 genera (WSC, 2021). All these spiders were distributed in all the Indian states except
Nagaland and two union territories, Dadra and Nagar Haveli and Daman and Diu, and Lakshadweep (Fig. 1). Eight species marked with $t$ seem to be erroneous report or misidentification. Caleb and Sankaran (2021) enlisted only 130 species of Lycosidae described under 19 genera and the rest of the species recorded in India are either overlooked by them or are cases of misidentification. The distribution of one species, Hogna irascibilis (0. PickardCambridge, 1885) was mentioned in Turkmenistan in World Spider Catalogue (2021), but Pickard-Cambridge (1885) mentioned its type locality in Leh (Ladakh).

Maximum of 76 species of these spiders were recorded from Maharashtra followed by 65 species from West Bengal, 57 species from Gujarat, 50 species from Uttarakhand, 39 species from Madhya Pradesh, 38 species from Kerala, 36 species from Karnataka, 33 species from Jammu and Kashmir and less than 30 species are recorded from other states (Fig. 1). No species of wolf spiders is recorded from Nagaland and Dadra and Nagar Haveli and Daman and Diu. Indeed, no survey was conducted in these regions and need extensive researches in these regions.

Out of 155 species of Lycosidae recorded from India, 6 species are widely distributed (in more than 15 states and union territories), viz. Wadicosa fidelis (0. Pickard-Cambridge, 1872) (25 states, 3 union territories), Pardosa sumatrana (Thorell, 1890) (23 states, 1 union territory),Pardosa pseudoannulata (Bösenberg and Strand, 1906) (19 states, 1 union territory), Hippasa agelenoides (Simon, 1884) (17 states, 1 union territory), Hippasa greenalliae (Blackwall, 1867) (16 states, 1 union territory), and Lycosa tista Tikader, 


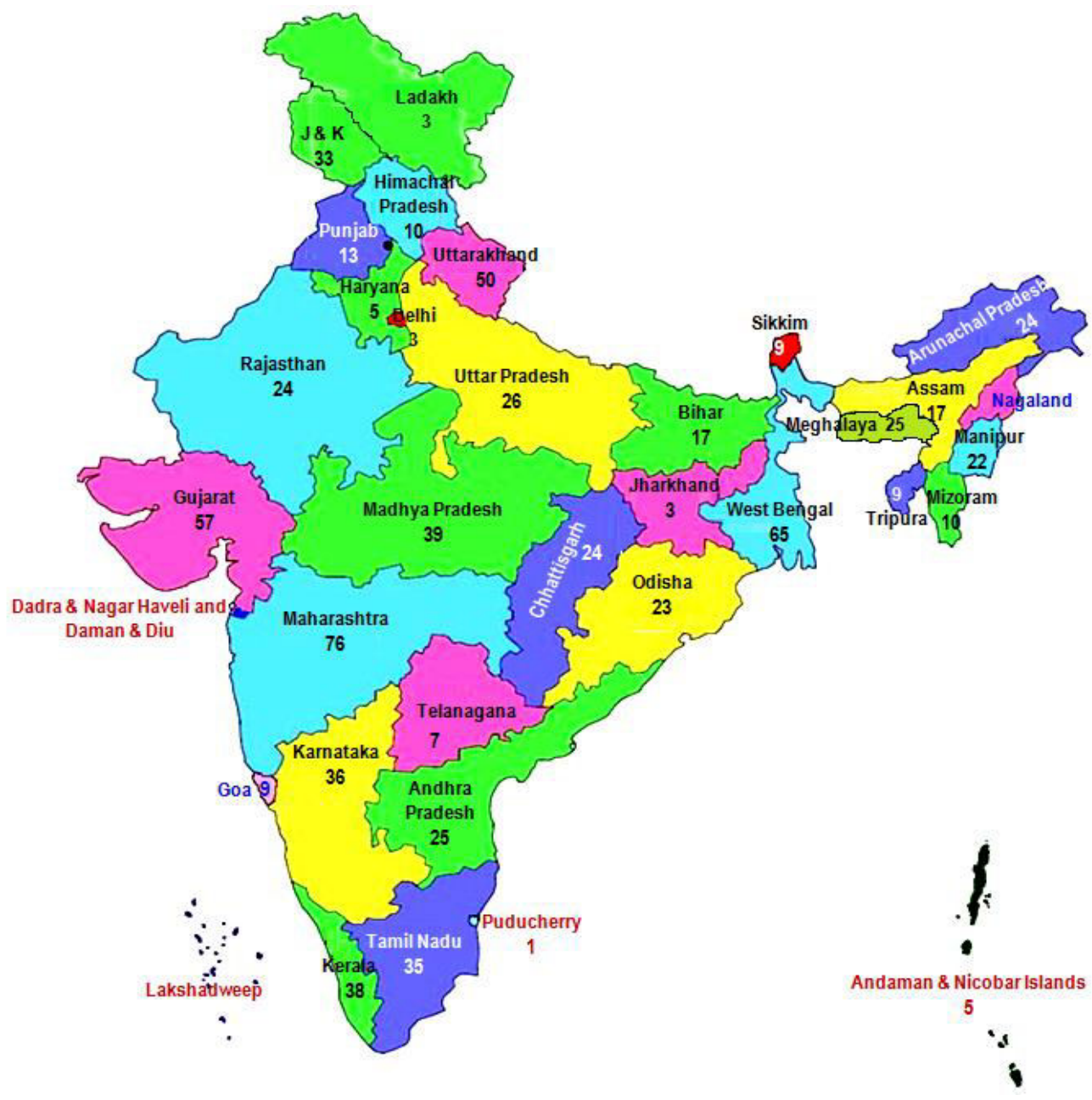

Figure 1: Number of species of wolf spiders (in Indian states and union territories)

1970 (16 states). About one-third of the species of Lycosidae reported from India are recorded only from one state or from the type locality. Hence, extensive faunistic surveys for these spiders are required.

Following is the detailed list of spiders distributed in Indian states and union territories and elsewhere:

\section{Checklist of wolf spiders (Lycosidae) in Indian States and Union Territories}

\section{Acantholycosa baltoroi (Caporiacco,} 1935)

Syn. Pardosa baltoroi Caporiacco, 1935
- Jammu and Kashmir (Caporiacco, 1935; Dhali et al., 2016)

Elsewhere: China, Nepal

2. Acantholycosa lignaria (Clerck, 1757)

- Maharashtra (Deshmukh and Tekade, 2019) Elsewhere: China, Europe, Russia

\section{Acantholycosa sp.}

- Gujarat (Parmar and Patel, 2015)

4. Agalenocosa subinermis (Simon, 1897)*

- Maharashtra (Dhali et al., 2016)

5. Alopecosa sp. 
- Jammu and Kashmir (Punjoo and Bhat, 2015)

\section{Anoteropsis hilaris (L. Koch, 1877)†}

Syn. Lycosa hilaris L. Koch, 1877

- Rajasthan (Kumari et al., 2017)

Elsewhere: Newzealand

\section{Arctosa himalayensis Tikader and Malhotra, 1980*}

Syn. Arctosa tappaensis Gajbe, 2004 (Sankaran et al., 2021)

- Chhattisgarh (Gajbe and Sharma, 1994; Kujur and Ekka, 2016)

- Jammu and Kashmir (Khan, 2006, 2011; Punjoo and Bhat, 2015)

- Madhya Pradesh (Gajbe and Singh, 1994; Gajbe P, 2004; Gajbe PU, 2004; Dhali et al., 2016)

- Maharashtra (Rithe, 2012)

- Uttar Pradesh (Biswas and Biswas, 1992; Khan and Misra, 2003; Dhali et al., 2016)

- Uttarakhand (Tikader and Malhotra, 1980)

- West Bengal (Tikader and Biswas, 1981; Biswas and Biswas, 1992; Majumder, 2004 a, 2005; Dhali et al., 2012, 2016, 2017)

\section{Arctosa indica Tikader and Malhotra, 1980*}

Syn. Arctosa indicus Tikader and Malhotra, 1980

- Chhattisgarh (Kujur and Ekka, 2016)

- Gujarat (Parmar and Patel, 2015)

- Jammu and Kashmir (Khan, 2006)

- Madhya Pradesh (Gajbe P, 2003; Gajbe PU, 2004)
- Maharashtra (Tikader and Malhotra, 1980; Biswas and Biswas, 1992; Rithe, 2012; Dhali et al., 2016)

- Rajasthan (Malhotra et al., 2019)

- Uttar Pradesh (Hore and Uniyal, 2008 a, b, c)

- Uttarakhand (Biswas and Biswas, 2010)

- West Bengal (Tikader and Biswas, 1981; Biswas and Biswas, 1992; Majumder, 2004 a, 2005; Talukdar and Majumder, 2008; Dhali et al., 2012, 2016, 2017)

\section{Arctosa khudiensis (Sinha, 1951)}

Syn. Lycosa khudiensis Sinha, 1951

- Bihar (Sinha, 1951; Tikader and Malhotra, 1980; Biswas and Majumder, 1995; Dhali et al., 2016)

- Gujarat (Yadav et al., 2017)

- Kerala (Mathew et al., 2014)

- Meghalaya (Biswas and Majumder, 1995; Majumder, 2004 a, 2005)

- Uttarakhand (Uniyal and Hore, 2006)

- West Bengal (Biswas and Majumder, 1995; Majumder, 2004 a, 2005)

Elsewhere: China

\section{Arctosa lesserti Reimoser 1934*}

Syn. Arctosa mulani (Dyal, 1935), m.i. by Tikader and Malhotra 1980 (Sankaran et al., 2021)

- Maharashtra (Tikader and Malhotra, 1980)

- Tamil Nadu (Reimoser, 1934; Dhali et al., 2016; Karthikeyani et al., 2017; Caleb and Karthikeyani, 2020)

\section{Arctosa littoralis (Hentz, 1844)†}

- Maharashtra (Wankhade and Manwar, 2016) 
Elsewhere: North and Central America

12. Arctosa mulani (Dyal, 1935)

- Gujarat (Yadav et al., 2017)

- Maharashtra (Biswas and Majumder, 1995;

More and Sawant, 2013; Dhali et al., 2016; Lu et al., 2016)

- Meghalaya (Biswas and Majumder, 1995; Majumder, 2004 a, 2005)

- Uttarakhand (Biswas and Biswas, 2010)

- West Bengal (Majumder, 2004 a, 2005)

Elsewhere: Pakistan

13. Arctosa sandeshkhaliensis Majumder, 2004*

- Jammu and Kashmir (Khan, 2011; Punjoo and Bhat, 2015)

- Madhya Pradesh (Gajbe PU, 2004; Dhali et al., 2016)

- Maharashtra (Rithe, 2012)

- West Bengal (Majumder, 2004 b, 2005; Dhali et al., 2016)

14. Arctosa sp.

- Gujarat (Parmar et al., 2015)

- Himachal Pradesh (Uniyal, 2006)

- Jammu and Kashmir (Khan, 2009; Khan and Rather, 2012)

- Karnataka (Nautiyal et al., 2017)

- Odisha (Siliwal and Molur, 2008)

- Tamil Nadu (Sugumaran et al., 2007)

- Uttar Pradesh (Hore and Uniyal ,2008 a, b, c)

- Uttarakhand (Gupta and Siliwal, 2012)

15. Crocodilosa leucostigma (Simon, 1885)*

Syn. Lycosa leucostigma Simon, 1885; Hippasa leucostigma (Simon, 1885)
- Bihar (Gravely, 1924)

- Karnataka (Simon, 1885 a)

- Kerala (Sunil Jose et al., 2008; Dhali et al., 2016)

- Maharashtra (Gravely, 1924)

- Odisha (Gravely, 1924)

- Tamil Nadu (Gravely, 1924; Dhali et al., 2016)

- West Bengal (Gravely, 1924)

16. Crocodilosa maindroni (Simon, 1897)* Syn. Lycosa maindroni Simon, 1897

- Maharashtra (Simon, 1897; Dhali et al., 2016)

17. Draposa amkhasensis (Tikader and Malhotra, 1976)*

Syn. Pardosa amkhasensis Tikader and Malhotra, 1976

- Chhattisgarh (Kujur and Ekka, 2016)

- Kerala (Sebastian et al., 2011)

- Madhya Pradesh (Tikader and Malhotra, 1976, 1980; Gajbe P, 2003; Gajbe UA, 2007; Dhali et al., 2016)

- Mizoram (Chowdhury et al., 2017)

- Tamil Nadu (Karthikeyani, 2013)

- West Bengal (Majumder, 2004 a; Sen et al., 2015; Dhali et al., 2012, 2016, 2017)

18. Draposa nicobarica (Thorell, 1891) Syn. Lycosa nicobarica Thorell, 1891; Pardosa nicobarica (Thorell, 1891)

- Andaman and Nicobar Islands (Roewer, 1955; Kronestedt, 2010; Dhali et al., 2016)

19. Draposa atropalpis (Gravely, 1924)

Syn. Pardosa atropalpis Gravely, 1924 
- Andhra Pradesh (Tikader and Malhotra, 1980; Biswas and Biswas, 1992; Majumder, 2004 a; Rao et al., 2005)

- Bihar (Tikader and Malhotra, 1980; Biswas and Biswas, 1992, 2004; Majumder, 2004 a)

- Karnataka (Gravely, 1924; Tikader and Malhotra, 1980; Biswas and Biswas, 1992, 2004; Majumder, 2004 a)

- Kerala (Sudhikumar et al., 2005 a; Sunil Jose et al., 2008; Joseph and Premila, 2016)

- Manipur (Biswas and Biswas, 2004; Kananbala et al., 2018)

- Odisha (Gravely, 1924; Tikader and Malhotra, 1980; Biswas, 1987; Biswas and Biswas, 1992; Biswas and Biswas, 2004; Majumder, 2004 a)

- Rajasthan (Kashmeera et al., 2020)

- Tamil Nadu (Gravely, 1924; Tikader and Malhotra, 1980; Biswas and Biswas, 1992; Biswas and Biswas, 2004; Majumder, 2004 a; Kronestedt, 2010; Dhali et al., 2016; Karthikeyani et al., 2017; Caleb, 2020 a)

- Telangana (Rao et al., 2005)

- Uttarakhand (Biswas and Biswas, 2010)

- West Bengal (Tikader and Malhotra, 1980; Biswas and Biswas, 1992, 2004; Majumder, 2004 a)

Elsewhere: Sri Lanka

20. Draposa burasantiensis (Tikader and Malhotra, 1976)

Syn. Pardosa burasantiensis Tikader and Malhotra, 1976

- Andhra Pradesh (Majumder, 2005)

- Bihar (Majumder, 2005)

- Karnataka (Majumder, 2005)
- Manipur (Kananbala et al., 2018)

- Odisha (Majumder, 2005)

- Tamil Nadu (Majumder, 2005)

- Uttarakhand (Biswas and Biswas, 2010)

- West Bengal (Tikader and Malhotra, 1976, 1980; Tikader and Biswas, 1981; Biswas and Biswas, 1992; Majumder, 2004 a, 2005; Dhali et al., 2012, 2016, 2017)

Elsewhere: China

\section{Draposa lyrivulva (Bösenberg and Strand, 1906)}

Syn. Lycosa lyrivulva Bösenberg and Strand, 1906; Pardosa leucopalpis Gravely, 1924

- Andhra Pradesh (Tikader and Malhotra, 1980; Majumder, 2004 a, 2005)

- Kerala (Tikader and Malhotra, 1980; Majumder, 2004 a, 2005)

- Maharashtra (More and Sawant, 2013)

- Odisha (Gravely, 1924; Tikader and Malhotra, 1980; Biswas, 1987; Majumder, $2004 \mathrm{a}, 2005$ )

- Tamil Nadu (Gravely, 1924; Reimoser, 1934; Tikader and Malhotra, 1980; Kronestedt, 2010; Karthikeyani et al., 2017; Caleb, 2020 b)

- Uttarakhand (Biswas and Biswas, 2010)

- West Bengal (Tikader and Biswas, 1981; Biswas and Biswas, 1992; Majumder, 2004 a, 2005; Talukdar and Majumder, 2008)

Elsewhere: Maldives, Pakistan, Sri Lanka

\section{Draposa nicobarica (Thorell, 1891)*}

Syn. Lycosa nicobarica Thorell 1891; Pardosa nicobarica (Thorell 1891)

- Andaman and Nicobar Islands (Thorell, 1891; Roewer, 1955; Kronestedt, 2010; Dhali et al., 2016) 


\section{Draposa oakleyi (Gravely, 1924)}

Syn. Pardosa oakleyi Gravely 1924

- Arunachal Pradesh (Biswas and Biswas, 2006)

- Bihar (Gravely, 1924; Biswas and Biswas, 1992, 2006, 2007; Dhali et al., 2016)

- Gujarat (Dhali et al., 2016)

- Karnataka (Biswas and Biswas, 1992, 2006; Nautiyal et al., 2017)

- Kerala (Patel, 2003a)

- Mizoram (Biswas and Biswas, 2007)

- Odisha (Choudhury et al., 2019)

- Punjab (Biswas and Biswas, 1992, 2006, 2007; Kronestedt, 2010; Dhali et al., 2016)

- Tamil Nadu (Gravely, 1924; Tikader and Malhotra, 1980; Biswas and Biswas, 1992, 2006; Kronestedt, 2010; Dhali et al., 2016; Karthikeyani et al., 2017)

- Uttarakhand (Biswas and Biswas 2010)

- West Bengal (Biswas and Biswas, 1992, 2006, 2007; Majumder, 2004 a, 2005)

Elsewhere: Bangladesh, Pakistan, United Arab Emirates

\section{Draposa porpaensis (Gajbe, 2004)*}

Syn. Pardosa porpaensis Gajbe, 2004

- Chhattisgarh (Gajbe UA, 2004; Dhali et al., 2016)

25. Draposa subhadrae (Patel and Reddy, 1993)

Syn. Pardosa subhadrae Patel and Reddy, 1993

- Andhra Pradesh (Patel and Reddy, 1993; Dhali et al., 2016)

- Maharashtra (More and Sawant, 2013)

Elsewhere: Sri Lanka

\section{Draposa sp.}

- West Bengal (Saha et al., 2017)

27. Evippa banarensis Tikader and Malhotra, 1980*

- Gujarat (Patel and Vyas, 2001; Yadav et al., 2017)

- Kerala (Adarsh and Nameer, 2016)

- Maharashtra (Rithe, 2012; More and Sawant, 2013)

- Meghalaya (Biswas and Majumder, 1995)

- Rajasthan (Tikader and Malhotra, 1980; Tikader, 1982; Biswas and Majumder, 1995; Dhali et al., 2016; Jangid et al., 2019)

\section{Evippa jabalpurensis Gajbe, 2004*}

- Madhya Pradesh (Gajbe UA, 2004; Dhali et al., 2016)

- Maharashtra (Rithe, 2012)

29. Evippa mandlaensis Gajbe, 2004*

- Madhya Pradesh (Gajbe UA, 2004)

- Maharashtra (More and Sawant, 2013)

30. Evippa praelongipes (0. PickardCambridge, 1871)

- Assam (Tikader and Malhotra, 1980; Biswas and Majumder, 1995; Dhali et al., 2016)

- Gujarat (Patel and Pillai, 1988; Tikader and Malhotra, 1980; Trivedi, 2009; Dhali et al., 2016; Yadav et al., 2017)

- Meghalaya (Biswas and Majumder, 1995)

- Punjab (Tikader and Malhotra, 1980; Biswas and Majumder, 1995; Dhali et al., 2016)

- Rajasthan (Tikader and Malhotra, 1980; Biswas and Majumder, 1995; Dhali et al., 2016; Kumari et al., 2017)

- West Bengal (Biswas and Majumder, 1995) 
Elsewhere: Egypt, Israel, Kazakistan, Libya, North Africa, Pakistan (?), Russia, Saudi Arabia, Transcaspia, Tripoli, Turkmenistan (?), Yemen

31. Evippa rajasthanea Tikader and Malhotra, 1980*

Syn. Evippa rajasthaneus Tikader and Malhotra 1980

- Andhra Pradesh (Rao et al., 2005)

- Gujarat (Patel and Pillai, 1988; Trivedi, 2009; Yadav et al., 2017)

- Rajasthan (Tikader, 1982; Tikader and Malhotra, 1980; Dhali et al., 2016)

- Uttarakhand (Uniyal and Hore, 2006)

32. Evippa rubiginosa Simon, 1885*

- Andhra Pradesh (Gravely, 1924; Tikader and Malhotra, 1980; Dhali et al., 2016)

- Assam (Tikader and Malhotra, 1980; Dhali et al., 2016)

- Gujarat (Patel and Vyas, 2001; Yadav et al., 2017)

- Karnataka (Simon, 1885 a)

- Tamil Nadu (Tikader and Malhotra, 1980; Dhali et al., 2016)

33. Evippa shivajii Tikader and Malhotra, 1980*

- Arunachal Pradesh (Biswas and Biswas, 2006)

- Gujarat (Yadav et al., 2017)

- Maharashtra (Tikader and Malhotra, 1980; Biswas and Biswas, 2006; More and Sawant, 2013; Dhali et al., 2016)

34. Evippa sohani Tikader and Malhotra, 1980*
- Gujarat (Patel and Pillai, 1988; Yadav et al., 2017)

- Himachal Pradesh (Uniyal, 2006)

- Maharashtra (Tikader and Malhotra, 1980;

Dhali et al., 2016)

- Uttarakhand (Uniyal and Hore, 2006)

35. Evippa solanensis Tikader and Malhotra, 1980*

- Himachal Pradesh (Tikader and Malhotra, 1980; Dhali et al., 2016)

- Uttar Pradesh (Uniyal and Hore, 2009)

36. Evippa sp.

- Gujarat (Siliwal et al., 2003; Parmar et al., 2015; Yadav et al., 2017)

- Jammu and Kashmir (Khan, 2011)

- Kerala (Sunil Jose et al., 2008)

- Odisha (Choudhury et al., 2019)

- West Bengal (Ghosh et al., 2018)

37. Evippomma evippiforme (Caporiacco, 1935)*

Syn. Pardosa evippiformis Caporiacco, 1935

- Jammu and Kashmir (Caporiacco, 1935; Dhali et al., 2016)

38. Evippomma evippinum (Simon, 1897)

- Maharashtra (Dhali et al., 2016)

Elsewhere: Pakistan

39. Geolycosa carli (Reimoser, 1934)*

Syn. Hogna carli Reimoser 1934

- Maharashtra (More and Sawant, 2013)

- Tamil Nadu (Reimoser, 1934; Dhali et al., 2016; Karthikeyani et al., 2017)

40. Geolycosa charitonovi (Mcheidze, 1997) 
- Maharashtra (Phartale et al., 2016)

Elsewhere: Azerbaijan, Georgia, Russia

\section{Geolycosa sp.}

- Odisha (Palita, 2016)

\section{Hippasa agelenoides (Simon, 1884)}

Syn. Hippasa greenalliae (Blackwall 1867) in Simon 1885a; Pirata agelenoides Simon, 1884

- Andhra Pradesh (Bastawade and Borkar, 2008)

- Arunachal Pradesh (Biswas and Biswas, 2006; Sen et al., 2015)

- Chhattisgarh (Gajbe and Sharma, 1994; Gajbe P, 2003; Kujur and Ekka, 2016)

- Goa (Bastawade and Borkar, 2008; Dhali et al., 2016; Pandit and Pai, 2017)

- Gujarat (Parmar and Patel, 2015; Yadav et al., 2017)

- Jammu and Kashmir (Punjoo and Bhat, 2015)

- Karnataka (Tikader and Malhotra, 1980; Biswas and Biswas, 2006; Sen et al., 2015; Dhali et al., 2016)

- Kerala (Tikader and Malhotra, 1980; Patel, 2003 a; Sudhikumar et al., 2005 a; Biswas and Biswas, 2006; Sunil Jose et al., 2008; Joseph and Premila, 2016)

- Madhya Pradesh (Gajbe UA, 1995, 2004; Sen et al., 2015; Dhali et al., 2016)

- Maharashtra (Tikader and Malhotra, 1980; Biswas and Biswas, 2006; More and Sawant, 2013; Sen et al., 2015; Dhali et al., 2016)

- Odisha (Panda et al., 2011; Mohapatra et al., 2014)

- Punjab (Kumari, 1983)
- Rajasthan (Chauhan et al., 2009; Kumari et al., 2017; Jangid et al., 2019)

- Tamil Nadu (Sherriffs, 1919; Simon, 1885 a; Tikader and Malhotra, 1980; Biswas and Biswas, 2006; Bastawade and Borkar, 2008; Sen et al., 2015; Dhali et al., 2016; Karthikeyani et al., 2017)

- Telangana (Sailu et al., 2017)

- Uttar Pradesh (Biswas and Biswas, 2006; Bastawade and Borkar, 2008; Sen et al., 2015; Kumar et al., 2017)

- Uttarakhand (Tikader and Malhotra, 1980; Biswas and Biswas, 2006; Bastawade and Borkar, 2008; Dhali et al., 2016)

- West Bengal (Majumder and Talukdar, 2013; Sen et al., 2015; Raychaudhuri et al., 2016; Saha et al., 2016; Dhali et al., 2012, 2016, 2017)

Elsewhere: Myanmar, Pakistan, Taiwan

43. Hippasa charamaensis Gajbe, 2004*

- Madhya Pradesh (Gajbe PU, 2004; Dhali et al., 2016)

- Maharashtra (Rithe, 2012)

44. Hippasa fabreae Gajbe and Gajbe, 1999*

- Madhya Pradesh (Gajbe and Gajbe, 1999 a; Gajbe P, 2003; Dhali et al., 2016)

45. Hippasa flavicoma Caporiacco, 1935*

- Jammu and Kashmir (Caporiacco, 1935; Dhali et al., 2016)

\section{Hippasa greenalliae (Blackwall, 1867)}

Syn. Lycosa greenalliae Blackwall, 1867; Hippasa pantherina Pocock, 1899

- Andhra Pradesh (Rao et al., 2005; Sen et al., 2015) 
- Chhattisgarh (Gajbe P, 2003; Gajbe and Sharma, 1994; Kujur and Ekka, 2016)

- Goa (Pandit and Pai, 2017)

- Gujarat (Patel, 2003 b; Yadav et al., 2017)

- Jammu and Kashmir (Sharma, 2014)

- Karnataka (Caleb, 2020 a; Tikader and Malhotra, 1980; Sen et al., 2015; Dhali et al., 2016)

- Kerala (Pocock, 1899, 1900; Tikader and Malhotra, 1980; Patel, 2003 a; Sudhikumar et al., 2005 a; Sunil Jose et al., 2008; Adarsh and Nameer, 2016; Dhali et al., 2016)

- Madhya Pradesh (Gajbe P, 2003; Gajbe UA, 2004; Keswani, 2014; Dhali et al., 2016)

- Maharashtra (Caleb, 2020 a; Tikader and Malhotra, 1980; More and Sawant, 2013; Dhali et al., 2016)

- Manipur (Biswas and Biswas, 2004; Kananbala et al., 2018)

- Odisha (Gravely, 1921; Tikader and Malhotra, 1980; Biswas, 1987; Biswas and Biswas, 2004; Panda et al., 2011; Sen et al., 2015; Palita, 2016; Dhali et al., 2016)

- Sikkim (Tikader, 1970; Tikader and Malhotra, 1980; Biswas and Biswas, 2004; Sen et al., 2015; Dhali et al., 2016)

- Tamil Nadu (Simon, 1885 a; Sherriffs, 1919; Tikader and Malhotra, 1980; Sen et al., 2015; Dhali et al., 2016; Karthikeyani et al., 2017; Caleb, 2020 a, b)

- Tripura (Dey et al., 2013)

- Uttar Pradesh (Blackwall, 1867; Sen et al., 2015)

- Uttarakhand (Biswas and Biswas, 2010; Quasin and Uniyal, 2013)
- West Bengal (Tikader and Malhotra, 1980; Biswas and Biswas, 1992; Majumder, 2004 a, 2005; Dhali et al., 2012, 2016, 2017; Majumder and Talukdar, 2013; Sen et al., 2015; Raychaudhuri et al., 2016; Saha et al., 2016)

Elsewhere: Bangladesh, Sri Lanka

\section{Hippasa hansae Gajbe and Gajbe, 1999*}

- Chhattisgarh (Ekka and Kujur, 2015)

- Madhya Pradesh (Gajbe and Gajbe, 1999 a; Gajbe P, 2003; Gajbe PU, 2004; Patil, 2012; Dhali et al., 2016)

- Maharashtra (Rithe, 2012; More and Sawant, 2013)

\section{Hippasa haryanensis Arora and Monga, 1994*}

- Haryana (Arora and Monga, 1994; Dhali et al., 2016)

- Punjab (Singh and Mavi, 1984)

49. Hippasa himalayensis Gravely $1924 *$

- Assam (Saha et al., 2016)

- Himachal Pradesh (Dhali et al., 2016)

- Jammu and Kashmir (Sharma, 2014)

- Karnataka (Saha et al., 2016)

- Kerala (Dhali et al., 2016)

- Meghalaya (Gravely, 1924)

- Tamil Nadu (Tikader and Malhotra, 1980)

- Uttar Pradesh (Hore, 2009)

- West Bengal (Majumder and Talukdar, 2013; Raychaudhuri et al., 2016; Dhali et al., 2016; Saha et al., 2016)

\section{Hippasa holmerae Thorell, 1895}

- Arunachal Pradesh (Biswas and Biswas, 2006) 
- Gujarat (Thumar, 2019)

- Jammu and Kashmir (Khan, 2006)

- Karnataka (Deshpande and Paul, 2016)

- Kerala (Sebastian et al., 2011; Joseph and Premila, 2016; Adarsh and Nameer, 2016)

- Maharashtra (More and Sawant, 2013; Deshmukh and Tekade, 2019)

- Manipur (Tikader and Biswas, 1981; Biswas and Biswas, 1992, 2006; Biswas and Majumder, 2000; Majumder, 2005; Dhali et al., 2016)

- Tripura (Biswas and Majumder, 2000)

- Uttar Pradesh (Biswas and Biswas, 1992, 2006; Biswas and Majumder, 2000; Majumder, 2005; Sharma and Singh, 2018 a, b)

- Uttarakhand (Tikader and Malhotra, 1980; Biswas and Biswas, 2010; Dhali et al., 2016)

- West Bengal (Tikader and Malhotra, 1980; Tikader and Biswas, 1981; Biswas and Biswas, 1992, 2006; Biswas and Majumder, 2000; Majumder, 2005; Talukdar and Majumder, 2008; Majumder and Talukdar, 2013; Dhali et al., 2016)

Elsewhere: Bangladesh, China, Philippines, Taiwan

\section{Hippasa loundesi Gravely, 1924*}

- Gujarat (Prajapati et al., 2016; Yadav et al., 2017)

- Tamil Nadu (Gravely, 1924; Tikader and Malhotra, 1980; Karthikeyani, 2013; Dhali et al., 2016; Karthikeyani et al., 2017)

- Uttarakhand (Biswas and Biswas, 2010)

52. Hippasa lycosina Pocock, 1900
Syn. Hippasa nilgiriensis Gravely, 1924; Hippasa mahabaleshwarensis Tikader and Malhotra, 1980

- Delhi (Malik et al., 2015)

- Gujarat (Patel, 2003 b; Siliwal et al., 2003; Kumar and Shivakumar, 2004)

- Karnataka (Caleb, 2020 a)

- Kerala (Tikader and Malhotra, 1980; Patel, 2003 a; Sudhikumar et al., 2005 a; Sunil Jose et al., 2008; Dhali et al., 2016)

- Maharashtra (Caleb, 2020 a; Tikader and Malhotra, 1980; Biswas and Majumder, 1995; Bastawade and Khandal, 2006; Dhali et al., 2016)

- Manipur (Kananbala et al., 2018)

- Meghalaya (Biswas and Majumder, 1995)

- Tamil Nadu (Gravely, 1924; Tikader and Malhotra, 1980; Dhali et al., 2016; Karthikeyani et al., 2017; Saranya et al., 2019)

- Uttarakhand (Tikader and Malhotra, 1980; Bastawade and Khandal, 2006; Biswas and Biswas, 2010; Dhali et al., 2016)

Elsewhere: China, Laos

\section{Hippasa madhuae Tikader and Malhotra, 1980*}

- Gujarat (Patel, 2003 b)

- Maharashtra (Tikader and Malhotra, 1980; Biswas and Biswas, 1992; Bastawade, 2008 a; Rithe, 2012; More and Sawant, 2013; Dhali et al., 2016)

- Rajasthan (Sen et al., 2009; Kaur et al., 2014; Lawania and Trigunayat, 2015; Saha et al., 2015; Dhali et al., 2016)

-West Bengal (Biswas and Biswas, 1992)

54. Hippasa madraspatana Gravely, 1924* 
Syn. Lycosa madraspatana (Gravely, 1924), misnamed by Umarani and Umamaheswari, 2013

- Gujarat (Tikader and Malhotra, 1980; Sen et al., 2015; Dhali et al., 2016; Yadav et al., 2017)

- Meghalaya (Biswas and Majumder, 1995)

- Tamil Nadu (Gravely, 1924; Tikader and Malhotra, 1980; Biswas and Majumder, 1995; Umarani and Umamaheswari, 2013; Sen et al., 2015; Dhali et al., 2016; Karthikeyani et al., 2017; Caleb, 2020 a)

- Uttarakhand (Biswas and Biswas, 2010)

- West Bengal (Sen et al., 2015; Dhali et al., 2012, 2016, 2017)

\section{Hippasa olivacea (Thorell, 1887)}

- Andhra Pradesh (Rao et al., 2005)

- Goa (Dhali et al., 2016)

- Gujarat (Yadav et al., 2017)

- Karnataka (Bastawade and Borkar, 2008)

- Kerala (Sudhikumar et al., 2005 a; Sunil Jose et al., 2008)

- Madhya Pradesh (Gajbe P, 2003; Gajbe PU, 2004; Dhali et al., 2016)

- Maharashtra (Bastawade, 2008 a; Bastawade and Borkar, 2008)

- Mizoram (Biswas and Biswas, 2007)

- Tamil Nadu (Bastawade and Borkar, 2008)

- Telangana (Rao et al., 2005)

- Uttarakhand (Leardi, 1901; Bastawade and Borkar, 2008)

- West Bengal (Majumder, 2004 a, 2005; Bastawade and Borkar, 2008)

Elsewhere: Myanmar
56. Hippasa partita (0. Pickard-Cambridge, 1876)

- Arunachal Pradesh (Biswas and Biswas, 2006)

- Chhattisgarh (Gajbe P, 2003; Gajbe PU, 2004)

- Gujarat (Tikader and Malhotra, 1980; Patel, 2003 b; Dhali et al., 2016; Yadav et al., 2017)

- Madhya Pradesh (Gajbe UA, 1995; Gajbe P, 2003; Patil, 2012; Dhali et al., 2016)

- Manipur (Biswas and Biswas, 2004; Kananbala et al., 2018)

- Mizoram (Biswas and Biswas, 2007)

- Odisha (Majumder, 2005)

- Rajasthan (Tikader and Malhotra, 1980; Dhali et al., 2016)

- Uttar Pradesh (Singh and Singh, 2014; Sharma and Singh, 2018 a, b)

- West Bengal (Biswas and Biswas, 1992, 2006; Saha et al., 1994; Majumder, 2004 a, 2005; Dhali et al., 2012; Majumder and Talukdar, 2013)

Elsewhere: Egypt, Bangladesh, Pakistan

\section{Hippasa pisaurina Pocock, 1900}

- Andhra Pradesh (Palem et al., 2016)

- Bihar (Gravely, 1924; Tikader and Malhotra, 1980; Dhali et al., 2016)

- Goa (Pandit and Pai, 2017)

- Gujarat (Tikader and Malhotra, 1980; Patel and Pillai, 1988; Patel and Vyas, 2001; Siliwal et al., 2003; Bhatt, 2014; Dhali et al., 2016; Yadav et al., 2017; Yadav and Kumar, 2019)

- Karnataka (Caleb, 2020 a; Gravely, 1924; Tikader and Malhotra, 1980; Dhali et al., 2016; Nautiyal et al., 2017) 
- Kerala (Patel, 2003 a; Adarsh and Nameer, 2015; Dhali et al., 2016)

- Madhya Pradesh (Gajbe and Singh, 1994; Gajbe UA, 1995, 2004; Patil, 2012; Dhali et al., 2016)

- Maharashtra (Caleb, 2020 a; Tikader, 1966; Tikader and Malhotra, 1980; Biswas and Biswas, 2004; Rithe, 2012; Dhali et al., 2016)

- Manipur (Biswas and Biswas, 2004; Kananbala et al., 2018)

- Rajasthan (Tikader, 1966; Chauhan et al., 2009; Kaur et al., 2014; Lawania and Trigunayat, 2015; Kumari et al., 2017; Jangid et al., 2019)

- Tamil Nadu (Umarani and Umamaheswari, 2013)

- Uttar Pradesh (Hore and Uniyal, 2008 a, b, c)

- Uttarakhand (Uniyal and Hore, 2006)

- West Bengal (Biswas and Biswas, 2004; Ghosh et al., 2018)

Elsewhere: Bangladesh, Iraq, Pakistan

58. Hippasa valiveruensis Patel and Reddy, 1993*

- Andhra Pradesh (Patel and Reddy, 1993;

Dhali et al., 2016)

59. Hippasa wigglesworthi Gajbe and Gajbe, 1999*

- Madhya Pradesh (Gajbe and Gajbe, 1999 a; Gajbe P, 2003, Gajbe PU, 2004; Patil, 2012; Dhali et al., 2016)

\section{Hippasa sp.}

- Assam (Chetia and Kalita, 2012; Das et al., 2015)

- Chhattisgarh (Ekka and Kujur, 2015)
- Gujarat (Siliwal et al., 2003; Parasharya and Pathan, 2013; Parmar et al., 2015)

- Karnataka (Bhat et al., 2013)

- Kerala (Sebastian et al., 2005 a)

- Maharashtra (Nerlekar et al., 2016)

- Meghalaya (Bhattacharya et al., 2017)

- Mizoram (Chowdhury et al., 2017)

- Odisha (Siliwal and Molur, 2008)

- Rajasthan (Chauhan et al., 2009; Kumari et al., 2017; Jangid et al., 2019)

- Tamil Nadu (Kapoor, 2008)

- Uttar Pradesh (Hore and Uniyal, 2008,a, b)

\section{Hogna himalayensis (Gravely, 1924)}

Syn. Lycosa himalayensis Gravely, 1924

- Andhra Pradesh (Majumder, 2005)

- Assam (Biswas and Majumder, 1995; Biswas and Biswas, 2004; Sen et al., 2015; Dhali et al., 2016)

- Karnataka (Sen et al., 2015)

- Kerala (Sen et al., 2015)

- Maharashtra (Sen et al., 2015)

- Manipur (Biswas and Biswas, 2004; Sen et al., 2015)

- Meghalaya (Biswas and Majumder, 1995; Biswas and Biswas, 2004; Sen et al., 2015)

- Tamil Nadu (Sen et al., 2015)

- Uttar Pradesh (Sen et al., 2015)

- Uttarakhand (Biswas and Biswas, 2010)

- West Bengal (Gravely, 1924; Tikader and Malhotra, 1980; Biswas and Biswas, 1992; Biswas and Majumder, 1995; Majumder, 2004 a, 2005; Majumder and Talukdar, 2013; Sen et al., 2015; Dhali et al., 2012, 2016, 2017) 
Elsewhere: Bhutan, China

62. Hogna irascibilis (0. PickardCambridge, 1885)*

Syn. Tarentula irascibilis $0 . \quad$ PickardCambridge, 1885

- Ladakh (Pickard-Cambridge, 1885)

63. Hogna lenta (Hentz, 1844)†

- Odisha (Palita, 2016)

Elsewhere: USA

\section{Hogna rubromandibulata (0. Pickard- Cambridge, 1885)}

Syn. Lycorma rubromandibulata 0. PickardCambridge, 1885; Trochosa rubromandibulata (O. Pickard-Cambridge, 1885)

- Jammu and Kashmir (Pickard-Cambridge, 1885; Caporiacco, 1935; Dhali et al., 2016)

Elsewhere: Pakistan

\section{Hogna stictopyga (Thorell, 1895)}

- Bihar (Gravely, 1924; Dhali et al., 2016)

- Maharashtra (More and Sawant, 2013)

- Punjab (Dhali et al., 2016)

- Uttarakhand (Leardi, 1901)

- West Bengal (Gravely, 1924; Dhali et al., 2016)

Elsewhere: Myanmar, Singapore

66. Lycosa arambagensis Biswas and Biswas, 1992*

- West Bengal (Biswas and Biswas, 1992; Dhali et al., 2016)

67. Lycosa balaramai Patel and Reddy, 1993*

- Andhra Pradesh (Patel and Reddy, 1993;

Dhali et al., 2016)
- Maharashtra (More and Sawant, 2013)

68. Lycosa barnesi Gravely, 1924*

- Kerala (Gravely, 1924; Tikader and Malhotra, 1980; Biswas and Biswas, 2004; Dhali et al., 2016; Adarsh and Nameer, 2016)

- Maharashtra (Rithe, 2012)

- Manipur (Biswas and Biswas, 2004; Kananbala et al., 2018)

- Meghalaya (Biswas and Majumder, 1995; Biswas and Biswas, 2004)

- Tamil Nadu (Saranya et al., 2019)

69. Lycosa bhatnagari Sadana, 1969*

- Maharashtra (Rithe, 2012; More and Sawant, 2013)

- Punjab (Sadana, 1969; Dhali et al., 2016)

70. Lycosa bistriata Gravely, 1924

- Chhattisgarh (Kujur and Ekka, 2016)

- Arunachal Pradesh (Biswas and Biswas, 2006)

- Bihar (Gajbe PU, 2004)

- Gujarat (Patel, 2003 b)

- Karnataka (Gravely, 1924; Nautiyal et al., 2017)

- Kerala (Adarsh and Nameer, 2016)

- Madhya Pradesh (Gajbe P, 2003; Sen et al., 2015; Dhali et al., 2016)

- Maharashtra (Rithe, 2012)

- Manipur (Kananbala et al., 2018)

- Rajasthan (Jangid et al., 2019)

- Tamil Nadu (Gravely, 1924; Tikader and Malhotra, 1980; Biswas and Biswas, 2006; Sen et al., 2015; Dhali et al., 2016; Karthikeyani et al., 2017; Caleb, 2020 a) 
- West Bengal (Gravely, 1924; Sinha, 1951; Biswas and Biswas, 2006; Majumder and Talukdar, 2013; Sen et al., 2015; Dhali et al., 2012, 2016, 2017)

Elsewhere: Bhutan

\section{Lycosa carmichaeli Gravely, 1924*}

- Arunachal Pradesh (Biswas and Biswas, 2006)

- Assam (Gravely, 1924; Tikader, 1970; Tikader and Malhotra, 1980; Biswas and Biswas, 2006; Bastawade and Borkar, 2008; Sen et al., 2015; Dhali et al., 2016)

- Goa (Bastawade and Borkar, 2008; Dhali et al., 2016)

- Jharkhand (Agrawal and Ghose, 1995)

- Kerala (Sudhikumar et al., 2005 a; Joseph et al., 2017)

- Meghalaya (Biswas and Biswas, 2006)

- Sikkim (Tikader, 1970)

- Uttar Pradesh (Gravely, 1924; Biswas and Biswas, 2006; Bastawade and Borkar, 2008; Sen et al., 2015; Dhali et al., 2016)

- Uttarakhand (Gravely, 1924; Tikader, 1970; Tikader and Malhotra, 1980; Bastawade and Borkar, 2008)

- West Bengal (Gravely, 1924; Tikader, 1970; Tikader and Malhotra, 1980; Biswas and Biswas, 1992, 2006; Bastawade and Borkar, 2008; Dhali et al., 2012, 2016, 2017; Majumder and Talukdar, 2013; Sen et al., 2015)

\section{Lycosa chaperi Simon, 1885}

- Andhra Pradesh (Tikader and Malhotra, 1980; Dhali et al., 2016)

- Gujarat (Patel and Vyas, 2001; Yadav et al., 2017)
- Karnataka (Simon, 1885 a)

- Punjab (Sadana, 1972; Tikader and Malhotra, 1980; Dhali et al., 2016)

- Tamil Nadu (Pocock, 1900; Sherriffs, 1919; Karthikeyani et al., 2017)

- Uttarakhand (Biswas and Biswas, 2010)

- West Bengal (Majumder, 2004 a, 2005)

Elsewhere: Pakistan

\section{Lycosa choudhuryi Tikader and Malhotra, 1980}

- Maharashtra (Rithe, 2012)

- West Bengal (Tikader and Malhotra, 1980; Biswas and Biswas, 1992; Majumder, 2004 a, 2005; Talukdar and Majumder, 2008; Dhali et al., 2016)

Elsewhere: China

\section{Lycosa fuscana Pocock, 1901*}

- Arunachal Pradesh (Biswas and Biswas, 2006)

- Maharashtra (Pocock, 1901; Tikader and Malhotra, 1980; Biswas and Biswas, 2006; More and Sawant, 2013; Dhali et al., 2016)

- Uttarakhand (Biswas and Biswas, 2010)

75. Lycosa geotubalis Tikader and Malhotra, 1980*

- Gujarat (Tikader and Malhotra, 1980; Biswas and Majumder, 1995; Patel and Vyas, 2001; Patel, 2003 b; Parmar et al., 2015; Dhali et al., 2016; Yadav et al., 2017)

- Jammu and Kashmir (Khan, 2006)

- Maharashtra (Tikader and Malhotra, 1980; Biswas and Majumder, 1995; More and Sawant, 2013; Dhali et al., 2016)

- Meghalaya (Biswas and Majumder, 1995) 
- Tamil Nadu (Ganesh Kumar and Velusamy, 1996)

\section{Lycosa goliathus Pocock, 1901*}

- Gujarat (Patel and Vyas, 2001; Yadav et al., 2017)

- Maharashtra (Pocock, 1901; Tikader and Malhotra, 1980; Dhali et al., 2016)

\section{Lycosa grahami Fox, 1935†}

- Gujarat (Siliwal, 2000; Kumar and Shivakumar, 2006)

Elsewhere: China

\section{Lycosa indagatrix Walckenaer, 1837}

Syn. Lycosa catula Simon, 1885

- Andhra Pradesh (Gravely, 1924; Tikader and Malhotra, 1980; Rao et al., 2005; Biswas and Biswas, 2006; Dhali et al., 2016)

- Arunachal Pradesh (Biswas and Biswas, 2006)

- Karnataka (Simon, 1885 b; Pocock, 1900; Gravely, 1924; Reimoser, 1934)

- Maharashtra (More and Sawant, 2013)

- Puducherry (Simon, 1984, 1885 a; Pocock, 1900)

- Tamil Nadu (Walckenaer, 1837; Simon, 1885 b; Pocock, 1900; Sherriffs, 1919; Gravely, 1924; Reimoser, 1934; Tikader and Malhotra, 1980; Biswas and Biswas, 2006; Dhali et al., 2016; Karthikeyani et al., 2017; Caleb, 2020 a)

- West Bengal (Dhali et al., 2012, 2016, 2017)

Elsewhere: Sri Lanka

\section{Lycosa iranii Pocock, 1901*}

- Arunachal Pradesh (Biswas and Biswas, 2006)
- Delhi (Malik et al., 2015)

- Gujarat (Patel and Vyas, 2001; Parmar et al., 2015; Yadav et al., 2017)

- Maharashtra (Pocock, 1901; Tikader and Malhotra, 1980; Biswas and Majumder, 1995; Biswas and Biswas, 2006; Dhali et al., 2016)

- Manipur (Biswas and Biswas, 2004; Kananbala et al., 2018)

- Meghalaya (Biswas and Majumder, 1995; Biswas and Biswas, 2004, 2006)

- Odisha (Choudhury et al., 2019)

- Uttarakhand (Biswas and Biswas, 2010)

80. Lycosa jagadalpurensis Gajbe, 2004*

- Chhattisgarh (Gajbe UA, 2004; Kujur and Ekka, 2016)

- Madhya Pradesh (Dhali et al., 2016)

- Maharashtra (Rithe, 2012)

81. Lycosa kempi Gravely, 1924

- Andhra Pradesh (Rao et al., 2005)

- Arunachal Pradesh (Biswas and Biswas, 2006; Dhali et al., 2016)

- Assam (Sinha, 1951; Tikader, 1970; Tikader and Malhotra, 1980; Biswas and Biswas, 1992, 2006, 2006; Biswas and Majumder, 1995; Dhali et al., 2016)

- Manipur (Biswas and Biswas, 2004; Dhali et al., 2016; Kananbala et al., 2018)

- Meghalaya (Biswas and Majumder, 1995; Biswas and Biswas, 2004, 2006; Dhali et al., 2016)

- Sikkim (Tikader, 1970; Tikader and Malhotra, 1980; Biswas and Biswas 1992, 2004, 2006; Biswas and Majumder, 1995; Dhali et al., 2016) 
- West Bengal (Gravely, 1924; Sinha, 1951; Tikader, 1970; Tikader and Malhotra, 1980; Biswas and Biswas, 1992; Biswas and Majumder, 1995; Biswas and Biswas, 2004, 2006; Majumder, 2004 a, 2005; Talukdar and Majumder, 2008; Majumder and Talukdar, 2013; Dhali et al., 2012, 2016, 2017)

Elsewhere: Bhutan, China, Pakistan

\section{Lycosa Iambai Tikader and Malhotra, 1980*}

- Gujarat (Yadav et al., 2017)

- Maharashtra (Tikader and Malhotra, 1980; Dhali et al., 2016)

- Uttarakhand (Biswas and Biswas, 2010)

\section{Lycosa mackenziei Gravely, 1924}

- Assam (Singh et al., 2012; Basumatary and Brahma, 2017)

- Bihar (Gravely, 1924; Tikader and Malhotra, 1980; Biswas and Biswas, 1992; Sen et al., 2015; Dhali et al., 2016)

- Gujarat (Bhatt, 2014; Yadav et al., 2017)

- Haryana (Malik and Goyal, 2017)

- Jammu and Kashmir (Khan, 2006)

- Karnataka (Gravely, 1924; Tikader and Malhotra, 1980; Biswas and Biswas, 1992; Sen et al., 2015; Dhali et al., 2016; Fernandes and Ganesh, 2020)

- Kerala (Mathew et al., 2014; Sen et al., 2015; Dhali et al., 2016)

- Meghalaya (Bhattacharya et al., 2017)

- Odisha (Panda et al., 2011)

- Punjab (Tikader and Malhotra, 1980; Biswas and Biswas, 1992; Sen et al., 2015; Dhali et al., 2016)
- Rajasthan (Lawania and Trigunayat, 2015; Jangid et al., 2019)

- Tripura (Dey et al., 2013)

- Uttar Pradesh (Singh and Singh, 2014; Sharma and Singh, 2018 a, b)

- West Bengal (Gravely, 1924; Tikader and Malhotra, 1980; Biswas and Biswas, 1992; Majumder, 2004 a, 2005; Sen et al., 2015; Dhali et al., 2012, 2016, 2017; Ghosh et al., 2018)

Elsewhere: Bangladesh, Pakistan

\section{Lycosa madani Pocock, 1901*}

- Andhra Pradesh (Sen et al., 2015; Dhali et al., 2016)

- Arunachal Pradesh (Biswas and Biswas, 2006)

- Bihar (Biswas and Biswas, 2004; Sen et al., 2015; Dhali et al., 2016)

- Gujarat (Trivedi, 2009; Parasharya and Pathan, 2013; Yadav et al., 2017)

- Karnataka (Biswas and Biswas, 2004; Sen et al., 2015; Nautiyal et al., 2017)

- Kerala (Patel, 2003 a; Biswas and Biswas, 2004; Sunil Jose et al., 2008; Sen et al., 2015; Dhali et al., 2016)

- Madhya Pradesh (Gajbe and Singh, 1994)

- Maharashtra (Pocock, 1901; Tikader and Malhotra, 1980; Biswas and Biswas, 2004, 2006; Sen et al., 2015; Dhali et al., 2016)

- Manipur (Biswas and Biswas, 2004; Kananbala et al., 2018)

- Odisha (Biswas, 1987; Biswas and Biswas, 2004; Sen et al., 2015; Dhali et al., 2016)

- Rajasthan (Sivaperuman and Rathore, 2004)

- Uttarakhand (Biswas and Biswas, 2010) 
- West Bengal (Sen et al., 2015; Dhali et al., 2016, 2017)

\section{Lycosa mahabaleshwarensis Tikader} and Malhotra, 1980*

- Goa (Bastawade and Borkar, 2008; Dhali et al., 2016)

- Gujarat (Siliwal et al., 2003; Yadav et al., 2017)

- Jharkhand (Agrawal and Ghose, 1995)

- Maharashtra (Tikader and Malhotra, 1980; Bastawade and Borkar, 2008; Rithe, 2012; Dhali et al., 2016)

- Tamil Nadu (Karthikeyani, 2013)

- Uttarakhand (Biswas and Biswas, 2010)

- West Bengal (Majumder, 2004 a, 2005)

\section{Lycosa masteri Pocock, 1901*}

- Maharashtra (Pocock, 1901; Tikader and Malhotra, 1980; Dhali et al., 2016)

- West Bengal (Majumder, 2004 a, 2005)

87. Lycosa moulmeinensis Gravely 1924†

- Gujarat (Yadav et al., 2017)

Elsewhere: Myanmar

\section{Lycosa nigrotibialis Simon, 1884}

- Assam (Tikader and Malhotra, 1980; Biswas and Majumder, 1995, 2000; Sen et al., 2015; Dhali et al., 2016)

- Bihar (Tikader and Malhotra, 1980; Biswas and Majumder, 1995, 2000; Dhali et al., 2016)

- Chhattisgarh (Gajbe and Sharma, 1994)

- Gujarat (Biswas and Majumder 1995, 2000; Dhali et al., 2016; Yadav et al., 2017)

- Himachal Pradesh (Tikader and Malhotra, 1980; Biswas and Majumder 1995, 2000; Dhali et al., 2016)
- Karnataka (Strand, 1909)

- Madhya Pradesh (Gajbe P, 2003; Gajbe UA, 2007; Patil, 2012; Dhali et al., 2016)

- Maharashtra (Tikader and Malhotra, 1980;

Biswas and Majumder, 1995, 2000; Bastawade, 2008 a; Dhali et al., 2016)

- Meghalaya (Biswas and Majumder, 1995)

- Sikkim (Tikader and Malhotra, 1980; Biswas and Majumder, 1995, 2000; Dhali et al., 2016)

- Telangana (Rao et al., 2005)

- Uttarakhand (Biswas and Biswas, 2010)

- West Bengal (Oppenheimer and Tikader, 1976)

Elsewhere: Bhutan, Myanmar

\section{Lycosa phipsoni Pocock, 1899}

- Assam (Dhali et al., 2016)

- Goa (Bastawade and Borkar, 2008; Dhali et al., 2016)

- Gujarat (Siliwal, 2000; Yadav et al., 2017)

- Karnataka (Pocock, 1900; Strand, 1909)

- Kerala (Sumesh and Sudhikumar, 2020)

- Maharashtra (Pocock, 1899, 1900; Sinha, 1951; Tikader and Malhotra, 1980; Bastawade and Khandal, 2006; Bastawade and Borkar, 2008; Sen et al., 2015; Dhali et al., 2016)

- Odisha (Sen et al., 2015; Dhali et al., 2016)

- Tripura (Biswas and Majumder, 2000)

- Uttarakhand (Biswas and Biswas, 2010)

- West Bengal (Tikader and Malhotra, 1980; Biswas and Majumder, 1995, 2000; Dhali et al., 2012, 2016; Majumder and Talukdar, 2013; Sen et al., 2015; Raychaudhuri et al., 2016; Saha et al., 2016, 2017)

Elsewhere: China, Taiwan 


\section{Lycosa pictula Pocock, 1901*}

- Arunachal Pradesh (Biswas and Biswas, 2006)

- Gujarat (Siliwal, 2000; Patel and Vyas, 2001;

Siliwal et al., 2003; Kumar and Shivakumar, 2004)

- Karnataka (Nautiyal et al., 2017)

- Maharashtra (Pocock, 1901; Tikader and Malhotra, 1980; Biswas and Biswas, 2006)

- Rajasthan (Lawania and Trigunayat, 2015; Jangid et al., 2019)

- Uttar Pradesh (Anjali and Prakash, 2012; Lawania and Mathur, 2014)

- Uttarakhand (Biswas and Biswas, 2010)

- West Bengal (Majumder, 2004 a, 2005)

91. Lycosa poonaensis Tikader and Malhotra, 1980*

- Andhra Pradesh (Palem et al., 2016)

- Arunachal Pradesh (Biswas and Biswas, 2006)

- Chhattisgarh (Gajbe P, 2003; Gajbe and Sharma, 1994; Kujur and Ekka, 2016; Ekka and Kujur, 2015)

- Gujarat (Patel and Pillai, 1988; Patel and Vyas, 2001; Siliwal et al., 2003; Parasharya and Pathan, 2013; Bhatt, 2014; Parmar and Patel, 2015; Yadav et al., 2017)

- Kerala (Sebastian et al., 2011)

- Madhya Pradesh (Gajbe UA, 1995; Keswani, 2014)

- Maharashtra (Tikader and Malhotra, 1980; Biswas and Biswas, 2006; Rithe, 2012; More and Sawant, 2013; Dhali et al., 2016; Lu et al., 2016)

- Mizoram (Chowdhury et al., 2017)
- West Bengal (Majumder, 2004 a, 2005;

Biswas and Biswas, 2006)

\section{Lycosa prolifica Pocock, 1901*}

- Arunachal Pradesh (Biswas and Biswas, 2006)

- Gujarat (Patel and Vyas, 2001; Patel, 2003 b; Yadav et al., 2017)

- Karnataka (Nautiyal et al., 2017)

- Maharashtra (Pocock, 1901; Tikader and Malhotra, 1980; Biswas and Biswas, 2006; Dhali et al., 2016)

- Odisha (Choudhury et al., 2019)

- Punjab (Tikader and Malhotra, 1980; Biswas and Biswas, 2006)

- Uttar Pradesh (Biswas and Biswas, 2006)

- Uttarakhand (Tikader and Malhotra, 1980; Biswas and Biswas, 2010)

93. Lycosa shahapuraensis Gajbe, 2004*

- Madhya Pradesh (Gajbe UA, 2004)

- Maharashtra (Rithe, 2012)

94. Lycosa shaktae Bhandari and Gajbe, 2001*

- Chhattisgarh (Kujur and Ekka, 2016; Ekka and Kujur, 2015)

- Madhya Pradesh (Bhandari and Gajbe, 2001; Gajbe P, 2003)

- Maharashtra (Rithe, 2012)

95. Lycosa shillongensis Tikader and Malhotra, 1980*

- Maharashtra (Meshram, 2011)

- Manipur (Biswas and Biswas, 2004; Sen et al., 2015; Dhali et al., 2016; Kananbala et al., 2018) 
- Meghalaya (Tikader and Malhotra, 1980; Biswas and Biswas, 1992, 2004; Biswas and Majumder, 1995; Majumder, 2005; Sen et al., 2015; Dhali et al., 2016)

- Mizoram (Biswas and Biswas, 2007)

- Uttarakhand (Biswas and Biswas, 2010)

- West Bengal (Biswas and Biswas, 1992; Majumder, 2005; Dhali et al., 2012, 2016, 2017; Sen et al., 2015)

96. Lycosa thoracica Patel and Reddy, 1993*

- Andhra Pradesh (Patel and Reddy, 1993; Dhali et al., 2016)

- Assam (Singh et al., 2012)

- Maharashtra (More and Sawant, 2013)

97. Lycosa tista Tikader, 1970

- Arunachal Pradesh (Biswas and Biswas, 2006; Dhali et al., 2016)

- Assam (Singh et al., 2012; Singh and Borkotoki, 2014)

- Goa (Halarnkar and Pai, 2018)

- Gujarat (Patel and Pillai, 1988; Siliwal et al., 2003; Trivedi, 2009; Parmar and Patel, 2015; Parmar et al., 2015; Yadav et al., 2017)

- Karnataka (Mubeen and Basavarajappa, 2018; Fernandes and Ganesh, 2020)

- Kerala (Mathew et al., 2014; Adarsh and Nameer, 2015, 2016; Dhali et al., 2016; Rajeevan et al., 2019)

- Madhya Pradesh (Patil et al., 2013)

- Maharashtra (Lanka et al., 2017)

- Manipur (Biswas and Biswas, 2004; Dhali et al., 2016, 2017; Kananbala et al., 2018)

- Mizoram (Chowdhury et al., 2017)
- Rajasthan (Jangid et al., 2019)

- Sikkim (Tikader, 1970; Tikader and Malhotra, 1980; Biswas and Biswas, 2004, 2006; Majumder, 2004 a, 2005)

- Tamil Nadu (Karthikeyani, 2013)

- Uttar Pradesh (Anjali and Prakash, 2012; Kumar et al., 2017)

- Uttarakhand (Biswas and Biswas, 2010; Siddhu et al., 2020)

- West Bengal (Majumder, 2004 a, 2005; Dhali et al., 2012, 2016, 2017; Sengupta et al., 2014)

Elsewhere: Bangladesh

\section{Lycosa wroughtoni Pocock, 1899*}

- Gujarat (Pocock, 1899, 1900; Tikader and Malhotra, 1980; Dhali et al., 2016; Yadav et al., 2017)

- Madhya Pradesh (Gajbe P, 2004)

- Punjab (Sadana, 1981)

99. Lycosa sp.

- Assam (Chetia and Kalita, 2012; Das et al., 2015)

- Chhattisgarh (Mishra and Shrivastava, 2002)

- Gujarat (Patel and Vyas, 2001; Siliwal et al., 2003; Parasharya and Pathan, 2013; Parmar and Patel, 2015; Parmar et al., 2015; Yadav et al., 2017)

- Jammu and Kashmir (Khan, 2009, 2011; Punjoo and Bhat, 2015)

- Karnataka (Nautiyal et al., 2017; Mubeen and Basavarajappa, 2018; Kokilamani et al., 2019)

- Kerala (Patel, 2003 a; Sebastian et al., 2005 a, b; Sunil Jose et al., 2008)

- Maharashtra (Nerlekar et al., 2016) 
- Rajasthan (Sivaperuman and Rathore, 2004; Chauhan et al., 2009; Kumari et al., 2017; Jangid et al., 2019; Malhotra et al., 2019)

- Tamil Nadu (Kapoor, 2008; Dharmaraj et al., 2018)

- Telangana (Sailu et al., 2017)

- Uttar Pradesh (Sharma and Singh, 2018 a)

- Uttarakhand (Pooja et al., 2019)

- West Bengal (Ghosh et al., 2018)

100. Lysania prolixa Malamel et al., 2015*

Syn. Lysania prolixus Malamel et al., 2015

- Kerala (Malamel et al., 2015; Joseph et al., 2017)

101. Margonia himalayensis (Gravely, 1924)*

Syn. Venonia himalayensis Gravely, 1924

- Gujarat (Biswas and Biswas, 2004; Yadav et al., 2017)

- Manipur (Biswas and Biswas, 2004; Kananbala et al., 2018)

- Meghalaya (Biswas and Majumder, 1995; Biswas and Biswas, 2004)

- West Bengal (Gravely, 1924; Tikader and Malhotra, 1980; Biswas and Biswas, 1992, 2004; Majumder and Talukdar, 2013; Dhali et al., 2016)

102. Ocyale kalpiensis Gajbe, 2004*

- Madhya Pradesh (Gajbe UA, 2004)

103. Ocyale pilosa (Roewer, 1960)

Syn. Ocyale atalanta Audouin, 1826

- Bihar (Tikader and Malhotra, 1980; Biswas and Majumder, 1995, 2000; Dhali et al., 2016)

- Meghalaya (Biswas and Majumder, 1995; Majumder, 2004 a, 2005)
- Odisha (Tikader and Malhotra, 1980; Biswas, 1987; Biswas and Majumder, 1995, 2000; Dhali et al., 2016)

- Tripura (Biswas and Majumder, 2000)

-West Bengal (Majumder, 2004 a, 2005)

Elsewhere: Madagascar, Saudi Arabia, Senegal, Sudan, Turkey

104. Ovia procurva (Yu and Song, 1988)

Syn. Pardosa procurva Yu and Song, 1988

- Kerala (Sankaran et al., 2017)

- West Bengal (Dhali et al., 2012, 2016, 2017)

Elsewhere: China, Taiwan

105. Ovia quinquedens (Dhali et al., 2012)*

Syn. Arctosa quinquedens Dhali et al., 2012

- West Bengal (Dhali et al., 2012, 2016, 2017; Sankaran et al., 2021)

106. Pardosa algoides Schenkel, 1963

- Arunachal Pradesh (Biswas and Biswas, 2006)

- Jammu and Kashmir (Biswas and Biswas, 2006; Khan, 2011; Khan and Rather, 2012; Marusik et al., 2014; Dhali et al., 2016)

- Ladakh (Tikader, 1977 a; Tikader and Malhotra, 1980; Uniyal, 2006)

- Uttarakhand (Biswas and Biswas, 2010)

Elsewhere: Bangladesh, China, Pakistan

\section{Pardosa alii Tikader, $1977^{*}$}

- Gujarat (Parmar et al., 2015)

- Jammu and Kashmir (Majumder, 2004 a, 2005; Dhali et al., 2016)

- Ladakh (Tikader, 1977 a; Tikader and Malhotra, 1980)

- West Bengal (Majumder, 2004,a, 2005) 
108. Pardosa altitudis Tikader and Malhotra, 1980

- Jammu and Kashmir (Khan, 2011; Khan and Rather, 2012)

- Karnataka (Nautiyal et al., 2017)

- Madhya Pradesh (Patil et al., 2013)

- Maharashtra (Rithe, 2012)

- Uttarakhand (Tikader and Malhotra, 1980;

Dhali et al., 2016)

Elsewhere: China

109. Pardosa balaghatensis Gajbe, 2004*

- Madhya Pradesh (Gajbe UA, 2004; Dhali et al., 2016)

- Maharashtra (Rithe, 2012)

110. Pardosa bargaonensis Gajbe, 2004*

- Chhattisgarh (Gajbe UA, 2004; Dhali et al., 2016)

- Maharashtra (Rithe, 2012)

111. Pardosa bastarensis Gajbe, 2004*

- Chhattisgarh (Gajbe UA, 2004; Dhali et al., 2016)

112. Pardosa chambaensis Tikader and Malhotra, 1976*

- Himachal Pradesh (Tikader and Malhotra, 1976, 1980; Sen et al., 2015; Dhali et al., 2016)

- Kerala (Sumesh and Sudhikumar, 2020)

- West Bengal (Majumder, 2004 a, 2005; Sen et al., 2015; Dhali et al., 2012, 2016, 2017)

113. Pardosa condolens (0. PickardCambridge, 1885)

- Jammu and Kashmir (Caporiacco, 1935)

Elsewhere: Central Asia, Iran

114. Pardosa debolinae Majumder, 2004*
- West Bengal (Majumder, 2004 c, 2005; Dhali et al., 2016)

115. Pardosa duplicata Saha et al., 1994*

- Maharashtra (Rithe, 2012)

- West Bengal (Saha et al., 1994; Dhali et al., 2012, 2016)

116. Pardosa flavisterna Caporiacco, 1935*

- Jammu and Kashmir (Caporiacco, 1935; Punjoo and Bhat, 2015; Dhali et al., 2016)

117. Pardosa fletcheri (Gravely, 1924)*

Syn. Lycosa fletcheri Gravely, 1924; Lycosa rothaka Tikader, 1970)

- Gujarat (Patel and Pillai, 1988)

- Himachal Pradesh (Gravely, 1924; Tikader and Malhotra, 1980; Dhali et al., 2016)

- Jammu and Kashmir (Sharma and Sharma, 1977; Khan, 2006)

- Punjab (Tikader and Malhotra, 1980; Dhali et al., 2016)

- Sikkim (Tikader, 1970; Tikader and Malhotra, 1980; Dhali et al., 2016)

- Uttar Pradesh (Dhali et al., 2016)

- Uttarakhand (Tikader and Malhotra, 1980)

118. Pardosa fuscula (Thorell, 1875)†

- Jammu and Kashmir (Punjoo and Bhat, 2015)

Elsewhere: Canada, USA

119. Pardosa gopalai Patel and Reddy, 1993*

- Andhra Pradesh (Patel and Reddy, 1993; Dhali et al., 2016)

\section{Pardosa haupti Song, 1995}

- Jammu and Kashmir (Marusik et al., 2014; Dhali et al., 2016) 
Elsewhere: China

\section{Pardosa heterophthalma (Simon, 1898)}

- Andhra Pradesh (Majumder, 2005)

- Arunachal Pradesh (Biswas and Biswas, 2006)

- Gujarat (Siliwal, 2000; Yadav et al., 2017)

- Meghalaya (Biswas and Majumder, 1995; Biswas and Biswas, 2006)

- Odisha (Majumder, 2005)

- Rajasthan (Sivaperuman and Rathore, 2004)

- Tamil Nadu (Tikader and Malhotra, 1980; Biswas and Biswas, 1992, 2006; Biswas and Majumder, 1995, 2000; Sen et al., 2015; Dhali et al., 2016)

- Tripura (Biswas and Majumder, 2000)

- Uttarakhand (Biswas and Biswas, 2010)

- West Bengal (Biswas and Biswas, 1992, 2006; Biswas and Majumder, 1995; Majumder, 2004 a, 2005; Dhali et al., 2012, 2016, 2017; Sen et al., 2015; Raychaudhuri et al., 2016; Saha et al., 2016)

Elsewhere: Bangladesh, Indonesia

\section{Pardosa hydaspis Caporiacco, 1935*}

- Jammu and Kashmir (Caporiacco, 1935; Dhali et al., 2016)

123. Pardosa jabalpurensis Gajbe and Gajbe, 1999*

- Chhattisgarh (Kujur and Ekka, 2016; Ekka and Kujur, 2015)

- Madhya Pradesh (Gajbe and Gajbe, 1999b; Gajbe P, 2003; Patil, 2012; Dhali et al., 2016)

- Maharashtra (Rithe, 2012)

124. Pardosa kalpiensis Gajbe, 2004*
- Madhya Pradesh (Gajbe UA, 2004; Dhali et al., 2016)

\section{Pardosa kupupa (Tikader, 1970)*}

Syn. Lycosa kupupa Tikader 1970

- Kerala (Sumesh and Sudhikumar, 2020)

- Sikkim (Tikader, 1970; Tikader and Malhotra, 1980; Sen et al., 2015; Dhali et al., 2016)

- Uttar Pradesh (Hore and Uniyal, 2008 a, b)

- Uttarakhand (Biswas and Biswas, 2010)

- West Bengal (Majumder, 2004 a, 2005; Talukdar and Majumder, 2008; Sen et al., 2015; Dhali et al., 2012, 2016)

Elsewhere: China

\section{Pardosa minuta Tikader and Malhotra, 1976}

- Gujarat (Kumar and Shivakumar, 2006; Yadav et al., 2017)

- Himachal Pradesh (Tikader and Malhotra, 1976, 1980; Biswas and Biswas, 2004; Bastawade, 2008 b; Dhali et al., 2016)

- Jammu and Kashmir (Thakur et al., 1995)

- Kerala (Sebastian et al., 2005 a, 2011)

- Maharashtra (Biswas and Majumder, 1995;

Biswas and Biswas, 2004)

- Manipur (Biswas and Biswas, 2004; Kananbala et al., 2018)

- Meghalaya (Biswas and Majumder, 1995; Biswas and Biswas, 2004)

- Uttar Pradesh (Hore and Uniyal, 2008 a, b)

- Uttarakhand (Biswas and Biswas, 2010)

- West Bengal (Majumder, 2005)

Elsewhere: Bangladesh 
127. Pardosa mukundi Tikader and Malhotra, 1980*

- Arunachal Pradesh (Biswas and Biswas, 2006)

- Chhattisgarh (Kujur and Ekka, 2016)

- Gujarat (Patel and Pillai, 1988; Siliwal, 2000; Kumar and Shivakumar, 2004; Prajapati et al., 2016)

- Madhya Pradesh (Gajbe P, 2003, Gajbe PU, 2004)

- Maharashtra (Tikader and Malhotra, 1980; Biswas and Biswas, 1992, 2006; Meshram, 2011; Rithe, 2012; More and Sawant, 2013; Dhali et al., 2016)

- Odisha (Choudhury et al., 2019)

- Tamil Nadu (Umarani and Umamaheswari, 2013)

- Uttarakhand (Biswas and Biswas, 2010)

- West Bengal (Biswas and Biswas, 1992, 2006)

128. Pardosa mysorensis (Tikader and Mukerji, 1971)*

Syn. Lycosa mysorensis Tikader and Mukerji, 1971

- Arunachal Pradesh (Biswas and Biswas, 2006)

- Gujarat (Yadav et al., 2017)

- Karnataka (Tikader and Mukerji, 1971; Tikader and Malhotra, 1980; Biswas and Biswas, 2006; Dhali et al., 2016)

- Kerala (Rajeevan et al., 2019)

- West Bengal (Majumder, 2004 a, 2005; Nautiyal et al., 2017)

129. Pardosa orcchaensis Gajbe, 2004*
- Chhattisgarh (Gajbe UA, 2004; Dhali et al., 2016)

130. Pardosa oriens (Chamberlin, 1924)

- Madhya Pradesh (Keswani, 2014)

- Maharashtra (Keswani and Vankhede, 2014)

Elsewhere: China, Japan, Okinawa

\section{Pardosa partita Simon, 1885*}

- Karnataka (Simon, 1885 a; Dhali et al., 2016)

- Madhya Pradesh (Gajbe and Singh, 1994)

- Maharashtra (Rithe, 2012; More and Sawant, 2013)

- Tamil Nadu (Hadole et al., 2015; Dhali et al., 2016)

\section{Pardosa pseudoannulata (Bösenberg and Strand, 1906)}

Syn. Lycosa annandalei Gravely, 1924; Pardosa annandalei (Gravely, 1924)

- Andhra Pradesh (Gravely, 1924; Tikader and Malhotra, 1980; Biswas and Biswas, 1992; Biswas and Majumder, 1995; Majumder, 2004 a, 2005)

- Assam (Tikader, 1964; Tikader and Malhotra, 1980; Biswas and Biswas, 1992; Biswas and Majumder, 1995; Singh et al., 2012; Singh and Borkotoki, 2014; Basumatary and Brahma, 2017)

- Bihar (Gravely, 1924; Tikader, 1964; Tikader and Malhotra, 1980; Biswas and Biswas, 1992; Biswas and Majumder, 1995; Yadav et al., 2016)

- Gujarat (Tikader and Malhotra, 1980; Biswas and Biswas, 1992; Biswas and Majumder, 1995; Patel and Vyas, 2001; Patel, 2003 b; Kumar and Shivakumar, 2004; Trivedi, 2009; Parasharya and Pathan, 2013; Parmar and Patel, 2015; Yadav et al., 2017) 
- Jammu and Kashmir (Thakur et al., 1995; Khan, 2006)

- Karnataka (Gravely, 1924; Tikader, 1964; Tikader and Malhotra, 1980; Biswas and Biswas, 1992; Nautiyal et al., 2017; Mubeen and Basavarajappa, 2018; Fernandes and Ganesh, 2020)

- Kerala (Gravely, 1924; Tikader, 1964; Tikader and Malhotra, 1980; Biswas and Biswas, 1992; Biswas and Majumder, 1995; Patel, 2003 a; Sudhikumar et al., 2005 b; Sebastian et al., 2005 a; Mathew et al., 2014; Adarsh and Nameer, 2015, 2016; Dhali et al., 2016)

- Madhya Pradesh (Tikader and Malhotra, 1980; Biswas and Biswas, 1992; Gajbe and Singh, 1994; Biswas and Majumder, 1995; Gajbe UA, 1995, 2004; Patil, 2012; Keswani, 2014)

- Maharashtra (Gravely, 1924; Tikader, 1964; Tikader and Malhotra, 1980; Biswas and Biswas, 1992; Biswas and Majumder, 1995; Keswani and Vankhede, 2014; Nerlekar et al., 2016)

- Manipur (Tikader and Malhotra, 1980; Majumder, 2004 a; Kananbala et al., 2018)

- Meghalaya (Tikader, 1964; Biswas and Majumder, 1995)

- Mizoram (Chowdhury et al., 2017)

- Odisha (Mohapatra et al., 2014; Palita, 2016)

- Punjab (Tikader, 1964)

- Rajasthan (Lawania and Trigunayat, 2015; Jangid et al., 2019; Malhotra et al., 2019)

- Tamil Nadu (Gravely, 1924; Tikader, 1964; Tikader and Malhotra, 1980; Biswas and Biswas, 1992; Biswas and Majumder, 1995; Ganesh Kumar and Velusamy, 1996;
Majumder, 2004 a; Dhali et al., 2016; Karthikeyani et al., 2017; Dharmaraj et al., 2018; Saranya et al., 2019; Caleb, 2020 b)

- Telangana (Anitha and Vijay, 2016)

- Uttar Pradesh (Khan and Misra, 2003; Anjali and Prakash, 2012; Singh and Singh, 2014; Sharma and Singh, $2018 \mathrm{a}$, b)

- Uttarakhand (Quasin and Uniyal, 2011; Siddhu et al., 2020)

- West Bengal (Gravely, 1924; Tikader, 1964; Tikader and Malhotra, 1980; Biswas and Biswas, 1992; Biswas and Majumder, 1995; Majumder, 2004 a, 2005; Dhali et al., 2012, 2016, 2017; Majumder and Talukdar, 2013; Sengupta et al., 2014)

Elsewhere: China, Indonesia, Japan, Korea, Laos, Pakistan, Philippines, Taiwan

\section{Pardosa pusiola (Thorell, 1891)}

Syn. Lycosa pusiola Thorell 1891

- Arunachal Pradesh (Biswas and Biswas, 2006)

- Chhattisgarh (Ekka and Kujur, 2015)

- Gujarat (Kumar and Shivakumar, 2004)

- Gujarat (Yadav et al., 2017)

- Karnataka (Nautiyal et al., 2017)

- Madhya Pradesh (Patil et al., 2013)

- Rajasthan (Sivaperuman and Rathore, 2004; Jangid et al., 2019)

- Tamil Nadu (Reimoser, 1934)

- West Bengal (Tikader and Malhotra, 1980; Biswas and Biswas, 2006; Majumder and Talukdar, 2013; Sen et al., 2015; Dhali et al., 2012, 2016, 2017)

Elsewhere: Bangladesh, Bhutan, China, Indonesia, Laos, Nepal, Malaysia, Myanmar, Sri 
Lanka

\section{Pardosa ranjani Gajbe, 2004*}

- Chhattisgarh (Ekka and Kujur, 2015)

- Madhya Pradesh (Gajbe PU, 2004; Patil, 2012; Dhali et al., 2016)

- Maharashtra (Rithe, 2012; More and Sawant, 2013)

\section{Pardosa rhenockensis (Tikader,} 1970)*

Syn. Lycosa rhenockensis Tikader, 1970

- Gujarat (Patel, 1971; Biswas and Biswas, 2007; Yadav et al., 2017)

- Kerala (Dhali et al., 2016)

- Madhya Pradesh (Patil et al., 2013)

- Manipur (Kananbala et al., 2018)

- Mizoram (Biswas and Biswas, 2007)

- Sikkim (Tikader, 1970; Tikader and Malhotra, 1980; Biswas and Biswas, 2007;

Dhali et al., 2016)

- Uttarakhand (Biswas and Biswas, 2010)

- West Bengal (Majumder, 2004 a, 2005)

\section{Pardosa shyamae (Tikader, 1970)}

Syn. Lycosa shyamae Tikader, 1970

- Gujarat (Siliwal et al., 2003; Bhatt, 2014; Yadav et al., 2017)

- Karnataka (Nautiyal et al., 2017)

- Kerala (Sudhikumar, 2007)

- Sikkim (Tikader, 1970)

- Uttarakhand (Biswas and Biswas, 2010; Pooja et al., 2019)

- West Bengal (Tikader, 1970; Tikader and Malhotra, 1980; Biswas and Biswas, 1992;
Majumder, 2005; Majumder and Talukdar, 2013; Dhali et al., 2016)

Elsewhere: Bangladesh, China

137. Pardosa songosa Tikader and Malhotra, 1976*

- Assam (Saha et al., 2016)

- Karnataka (Nautiyal et al., 2017)

- Rajasthan (Kaur et al., 2014; Lawania and Trigunayat, 2015)

- Uttar Pradesh (Tikader and Malhotra, 1976, 1980; Sen et al., 2015; Dhali et al., 2016)

- Uttarakhand (Tikader and Malhotra, 1976, 1980; Dhali et al., 2016; Gupta and Siliwal, 2012; Pooja et al., 2019)

- West Bengal (Majumder, 2004 a, 2005; Sengupta et al., 2014; Sen et al., 2015; Raychaudhuri et al., 2016; Dhali et al., 2012, 2016, 2017; Saha et al., 2016)

Elsewhere: Bangladesh, China

138. Pardosa stellata (0. PickardCambridge, 1885)

- Jammu and Kashmir (Caporiacco, 1935)

Elsewhere: Central Asia, China,

139. Pardosa suchismitae Majumder, 2004*

- West Bengal (Majumder, 2004 b, c, 2005; Dhali et al., 2016)

140. Pardosa sumatrana (Thorell, 1890)

Syn. Lycosa sumatrana Thorell, 1890

- Andaman and Nicobar Islands (Tikader, 1977 b; Bastawade and Khandal, 2006; Bastawade and Borkar, 2008)

- Andhra Pradesh (Tikader and Malhotra, 1980; Biswas and Biswas, 1992; Biswas and Majumder, 1995; Rao et al., 2005; Bastawade 
and Borkar, 2008; Sen et al., 2015; Palem et al., 2016; Dhali et al., 2016)

- Arunachal Pradesh (Tikader and Malhotra, 1980; Biswas and Majumder, 1995, 2000; Biswas and Biswas, 2004, 2006; Bastawade and Borkar, 2008; Sen et al., 2015; Dhali et al., 2016)

- Assam (Tikader, 197 7b; Singh et al., 2012; Singh and Borkotoki, 2014; Dhali et al., 2016)

- Bihar (Tikader, 1977 b; Tikader and Malhotra, 1980; Biswas and Biswas, 1992; Biswas and Majumder, 2000; Bastawade and Borkar, 2008; Sen et al., 2015; Dhali et al., 2012, 2016, 2017)

- Chhattisgarh (Gajbe P, 2003; Gajbe and Sharma, 1994)

- Goa (Bastawade and Borkar, 2008; Dhali et al., 2016)

- Gujarat (Tikader and Malhotra, 1980; Patel and Pillai, 1988; Biswas and Majumder, 1995, 2000; Siliwal, 2000; Patel and Vya,s 2001; Siliwal et al, 2003; Patel, 2003 b; Kumar and Shivakumar, 2004; Parasharya and Pathan, 2013; Bhatt, 2014; Sen et al., 2015; Yadav et al., 2017; Dhali et al., 2016)

- Haryana (Malik and Goyal, 2017)

- Himachal Pradesh (Tikader, 1977 b; Tikader and Malhotra, 1980; Biswas and Biswas, 1992; Biswas and Majumder, 1995, 2000; Bastawade and Borkar, 2008; Sen et al., 2015; Dhali et al., 2016)

- Karnataka (Tikader, 1977 b; Tikader and Malhotra, 1980; Biswas and Majumder, 1995; Bastawade and Borkar, 2008; Sen et al., 2015; Dhali et al., 2016; Nautiyal et al., 2017)

- Kerala (Tikader, 1977 b; Tikader and Malhotra, 1980; Biswas and Biswas, 1992; Sebastian et al., 2005 a, b; Sudhikumar, 2007;
Sunil Jose et al., 2008; Mathew et al., 2014; Adarsh and Nameer, 2015, 2016; Dhali et al., 2016)

- Madhya Pradesh (Tikader and Malhotra, 1980; Biswas and Majumder, 1995, 2000; Gajbe UA, 1995, 2004, 2007; Gajbe and Singh, 1994; Bastawade and Borkar, 2008; Patil, 2012; Sen et al., 2015; Dhali et al., 2016)

- Maharashtra (Tikader and Malhotra, 1980; Biswas and Majumder, 1995, 2000; Bastawade and Khandal, 2006; Bastawade and Borkar, 2008; Rithe, 2012; Dhali et al., 2016)

- Manipur (Biswas and Biswas, 2004; Sen et al., 2015; Kananbala et al., 2018)

- Meghalaya (Tikader and Malhotra, 1980; Biswas and Biswas, 1992, 2004; Biswas and Majumder, 1995, 2000; Bastawade and Borkar, 2008; Sen et al., 2015; Dhali et al., 2016)

- Odisha (Choudhury et al., 2019)

- Rajasthan (Tikader and Malhotra, 1980; Biswas and Majumder, 1995, 2000; Biswas and Biswas, 2004; Sivaperuman and Rathore, 2004; Chauhan et al., 2009; Sen et al., 2015; Dhali et al., 2016; Kumari et al., 2017)

- Tamil Nadu (Tikader, 1977 b; Tikader and Malhotra, 1980; Biswas and Biswas, 1992; Biswas and Majumder, 1995; Bastawade and Borkar, 2008; Umarani and Umamaheswari, 2013; Sen et al., 2015; Dhali et al., 2016; Karthikeyani et al., 2017; Dharmaraj et al., 2018)

- Telangana (Sailu et al., 2017)

- Tripura (Tikader and Biswas, 1981; Biswas and Majumder, 1995; Biswas and Biswas, 2004; Majumder, 2004 a, 2005)

- Uttar Pradesh (Tikader, 1977b; Singh and Singh, 2014; Kumar et al., 2017; Sharma and 
Singh, 2018 a, b)

- Uttarakhand (Biswas and Biswas, 2010; Quasin and Uniyal, 2011; Siddhu et al., 2020)

- West Bengal (Tikader, 1977 b; Tikader and Malhotra, 1980; Biswas and Biswas, 1992; Saha et al., 1994; Biswas and Majumder, 1995, 2000; Majumder, 2004 a, 2005; Bastawade and Borkar, 2008; Majumder and Talukdar, 2013; Sen et al., 2015; Dhali et al., 2016, 2017)

Elsewhere: Bangladesh, Bhutan, China, Indonesia, Myanmar, Nepal, Philippines, Sri Lanka

\section{Pardosa sutherlandi (Gravely, 1924)}

Syn. Lycosa sutherlandi Gravely, 1924

- Gujarat (Yadav et al., 2017)

- Jammu and Kashmir (Khan, 2006)

- Maharashtra (Rithe, 2012; Lu et al., 2016)

- Meghalaya (Biswas and Majumder, 1995)

- Tripura (Biswas and Majumder, 2000)

- West Bengal (Gravely, 1924; Tikader and Malhotra, 1980; Biswas and Biswas, 1992; Biswas and Majumder, 1995, 2000; Majumder, 2004 a, 2005; Majumder and Talukdar, 2013; Dhali et al., 2016)

Elsewhere: Nepal

142. Pardosa tappaensis Gajbe, 2004*

- Chhattisgarh (Gajbe UA, 2004; Dhali et al., 2016)

\section{Pardosa thalassia (Thorell, 1891)*}

Syn. Lycosa thalassia Thorell 1891

- Andaman and Nicobar Islands (Thorell, 1891; Dhali et al., 2016)

144. Pardosa tikaderi Arora and Monga, 1994*
- Haryana (Arora and Monga, 1994; Dhali et al., 2016)

\section{Pardosa timidula (Roewer, 1951)}

Syn. Lycosa timida Simon, 1882; Pardosa timida (Simon, 1882)

- Chhattisgarh (Kujur and Ekka, 2016)

- Gujarat (Yadav et al., 2017)

- Maharashtra (Patil et al., 2013)

- Manipur (Biswas and Biswas, 2004; Kananbala et al., 2018)

- Uttar Pradesh (Hore, 2009; Uniyal and Hore, 2009)

Elsewhere: Pakistan, Sri Lanka, Yemen

\section{Pardosa tridentis Caporiacco, 1935}

Syn. Lycosa tatensis Tikader, 1964; Pardosa tatensis (Tikader, 1964)

- Arunachal Pradesh (Biswas and Biswas, 2006)

- Gujarat (Siliwal et al., 2003; Yadav et al., 2017)

- Jammu and Kashmir (Caporiacco, 1935; Sen et al., 2015; Dhali et al., 2016)

- Uttarakhand (Sen et al., 2015; Dhali et al., 2016)

- West Bengal (Dhali et al., 2012, 2016, 2017;

Sen et al., 2015)

Elsewhere: Nepal

147. Pardosa vagula (Thorell, 1890)

Syn. Lycosa vagula Thorell, 1890

- Tamil Nadu (Reimoser, 1934)

Elsewhere: Indonesia

148. Pardosa vindicata (0. PickardCambridge, 1885) 
- Jammu and Kashmir (Caporiacco, 1935; Dhali et al., 2016)

Elsewhere: China

149. Pardosa sp.

- Andhra Pradesh (Palem et al., 2016)

- Arunachal Pradesh (Chetry and Moran, 2019)

- Assam (Das et al., 2015; Basumatary and Brahma, 2017)

- Bihar (Priyadarshini et al., 2015)

- Chhattisgarh (Mishra and Shrivastava, 2002;

Ekka and Kujur, 2015)

- Goa (Pandit and Dharwadkar, 2020)

- Gujarat (Patel and Vyas, 2001; Parasharya and Pathan, 2013; Parmar et al., 2015; Yadav et al., 2017)

- Jammu and Kashmir (Khan, 2009; Punjoo and Bhat, 2015)

- Karnataka (Nautiyal et al., 2017; Mubeen and Basavarajappa, 2018)

- Kerala (Patel, 2003 a; Sebastian et al., 2005 a; Adarsh and Nameer, 2015; Dhali et al., 2016)

- Rajasthan (Sivaperuman and Rathore, 2004; Chauhan et al., 2009; Kumari et al., 2017)

- Tamil Nadu (Kapoor, 2008)

- Tripura (Dey et al., 2013)

- Uttar Pradesh (Hore and Uniyal, 2008 a, b; Lawania and Mathur, 2014; Sharma and Singh, 2018 a)

- Uttarakhand (Pooja et al., 2019)

150. Pirata sp. +

- Bihar (Goswami et al., 2015)
151. Schizocosa concolor (Caporiacco, 1935)*

Syn. Hogna concolor Caporiacco, 1935

- Jammu and Kashmir (Caporiacco, 1935; Dhali et al., 2016)

152. Schizocosa sp.

- Maharashtra (Keswani and Vankhede, 2014)

153. Shapna pluvialis Hippa and Lehtinen, 1983*

- Meghalaya (Hippa and Lehtinen, 1983; Dhali et al., 2016)

154. Trochosa gunturensis Patel and Reddy, 1993*

- Andhra Pradesh (Patel and Reddy, 1993; Dhali et al., 2016)

- Maharashtra (Rithe, 2012; More and Sawant, 2013)

155. Trochosa himalayensis Tikader and Malhotra, 1980*

- Uttar Pradesh (Hore and Uniyal, 2008 a, b)

- Uttarakhand (Tikader and Malhotra, 1980; Biswas and Biswas, 2010; Dhali et al., 2016)

156. Trochosa propinqua 0. PickardCambridge, 1885*

- Jammu and Kashmir (Pickard-Cambridge, 1885; Caporiacco, 1935)

157. Trochosa punctipes (Gravely, 1924)*

Syn. Crocodilosa punctipes (Gravely, 1924); Lycosa punctipes Gravely, 1924

- Bihar (Gravely, 1924; Tikader, 1966; Majumder, 2004 a, 2005)

- Karnataka (Gravely, 1924; Tikader, 1966; Tikader and Malhotra, 1980; Majumder, 2004 a; Dhali et al., 2016) 
- Kerala (Sudhikumar, 2007; Mathew et al., 2014)

- Maharashtra (Tikader, 1966)

- Rajasthan (Tikader, 1966)

- Tamil Nadu (Gravely, 1924; Karthikeyani et al., 2017)

- Uttar Pradesh (Gravely, 1924; Tikader, 1966; Majumder, 2004 a, 2005)

- Uttarakhand (Biswas and Biswas, 2010)

- West Bengal (Gravely, 1924; Tikader, 1966; Majumder, 2004 a, 2005)

158. Trochosa terricola Thorell, 1856

Syn. Trochosina terricola (Simon, 1885)

- Jammu and Kashmir (Caporiacco, 1935)

Elsewhere: Caucasus, China, Central Asia, Europe, Iran, Japan, Kazakhstan, North America, Russia, Turkey

159. Trochosa urbana 0. PickardCambridge, 1876†

Syn. Geolycosa urbana (0. Pichard-Cambrige, 1876)

- Assam (Chetia and Kalita, 2012; Dhali et al., 2016)

- Maharashtra (Rithe, 2012)

- Rajasthan (Lawania and Trigunayat, 2015)

- Uttar Pradesh (Lawania and Mathur, 2014)

Elsewhere: Ethiopia, Iran, Israel, Madagascar, North Africa, Seychelles

160. Trochosa sp.

- Gujarat (Yadav et al., 2017)

- Karnataka (Mubeen and Basavarajappa, 2018)

- Kerala (Adarsh and Nameer, 2015; Sumesh and Sudhikumar, 2020)
- Madhya Pradesh (Gajbe P, 2004)

- Uttar Pradesh (Hore and Uniyal, 2008 a, b)

- Uttarakhand (Uniyal et al., 2011)

161. Wadicosa fidelis (0. PickardCambridge, 1872)

Syn. Lycosa birmanica (Simon, 1844); Pardosa bhatnagari Sadana, 1971; Pardosa birmanica Simon, 1844 (m.i. by Tikader and Malhotra, 1980, Tikader and Biswas, 1981; Gajbe UA, 2007; Sen et al., 2015 following Kronestedt, 2017); Wadicosa bhatnagari (Sadana, 1971)

- Andaman and Nicobar Islands (Tikader, 1977 b)

- Andhra Pradesh (Tikader and Malhotra, 1980; Biswas and Biswas, 1992; Biswas and Majumder, 1995; Rao et al., 2005; Bastawade and Khandal, 2006; Biswas and Biswas, 2006; Palem et al., 2016; Dhali et al., 2016)

- Arunachal Pradesh (Biswas and Biswas, 2006)

- Assam (Tikader, 1977 b; Singh et al., 2012; Singh and Borkotoki, 2014)

- Bihar (Tikader and Malhotra, 1980; Biswas and Biswas, 1992, 2004, 2006; Biswas and Majumder, 1995; Majumder, 2004 a; Bastawade and Khandal, 2006; Sen et al., 2015; Dhali et al., 2016)

- Chhattisgarh (Tikader and Biswas, 1981; Gajbe P, 2003; Gajbe and Sharma, 1994; Kujur and Ekka, 2016)

- Delhi (Malik et al., 2015)

- Gujarat (Tikader and Malhotra, 1980; Patel and Pillai, 1988; Biswas and Majumder, 1995; Siliwal, 2000; Patel and Vyas, 2001; Patel, 2003 b; Biswas and Biswas, 2004, 2006; Kumar and Shivakumar, 2004, 2006; Trivedi, 2009; Parasharya and Pathan, 2013; Parmar 
and Patel, 2015; Parmar et al., 2015; Dhali et al., 2016; Yadav et al., 2017; Yadav and Kumar, 2019)

- Haryana (Malik and Goyal, 2017)

- Himachal Pradesh (Tikader and Malhotra, 1980; Biswas and Biswas, 1992, 2006; Biswas and Majumder, 1995; Bastawade and Khandal, 2006; Sen et al., 2015; Dhali et al., 2016)

- Jammu and Kashmir (Sharma and Sharma, 1977; Thakur et al., 1995; Khan, 2006)

- Jharkhand (Tikader and Malhotra, 1980)

- Karnataka (Tikader, 1966; Biswas and Biswas, 1992, 2006; Nautiyal et al., 2017; Fernandes and Ganesh, 2020)

- Kerala (Patel, 2003 a; Adarsh and Nameer, 2015; Sumesh and Sudhikumar, 2020)

- Madhya Pradesh (Tikader and Malhotra, 1980; Biswas and Biswas, 1992, 2004, 2006; Biswas and Majumder, 1995; Gajbe UA, 1995; Gajbe and Singh, 1994; Patil, 2012; Dhali et al., 2016)

- Maharashtra (Tikader, 1966; Tikader and Malhotra, 1980; Biswas and Biswas, 1992, 2004, 2006; Biswas and Majumder, 1995; Bastawade and Khandal, 2006; Meshram, 2011; Rithe, 2012; More and Sawant, 2013; Keswani and Vankhede, 2014; Sen et al., 2015; Dhali et al., 2016; Lu et al., 2016)

- Manipur (Biswas and Biswas, 2004; Kananbala et al., 2018)

- Meghalaya (Tikader and Malhotra, 1980; Biswas and Majumder, 1995; Majumder, 2004 a; Biswas and Biswas, 2006, 2007; Sen et al., 2015; Dhali et al., 2016)

- Mizoram (Biswas and Biswas, 2007)

- Odisha (Tikader, 1977 b; Tikader and Malhotra, 1980; Biswas, 1987; Biswas and
Biswas, 1992, 2004, 2006; Biswas and Majumder, 1995; Majumder, 2004 a; Bastawade and Khandal, 2006; Panda et al, 2011; Sen et al., 2015; Dhali et al., 2016; Palita, 2016)

- Punjab (Tikader and Malhotra, 1980; Kumari, 1983; Biswas and Biswas, 1992, 2006; Biswas and Majumder, 1995; Bastawade and Khandal, 2006; Sen et al., 2015; Dhali et al., 2016)

- Rajasthan (Tikader, 1966; Tikader and Malhotra, 1980; Tikader and Biswas, 1981; Biswas and Biswas, 1992, 2004, 2006; Majumder, 2004 a; Sen et al., 2015; Kaur et al., 2014; Lawania and Trigunayat, 2015; Dhali et al., 2016; Jangid et al., 2019; Jangid et al., 2019)

- Tamil Nadu (Tikader, 1977 b; Tikader and Malhotra, 1980; Biswas and Biswas, 1992, 2004, 2006; Biswas and Majumder, 1995; Majumder, 2004 a; Karthikeyani, 2013; Umarani and Umamaheswari, 2013; Sen et al., 2015; Dhali et al., 2016, 2017; Karthikeyani et al., 2017; Saranya et al., 2019; Caleb, 2020 b)

- Telangana (Rao et al., 2005; Sailu et al., 2017)

- Tripura (Sen et al., 2015)

- Uttar Pradesh (Tikader, 1966; Biswas and Biswas, 1992, 2004, 2006; Biswas and Majumder, 1995; Khan and Misra, 2003; Hore and Uniyal, 2008 a, b, c; Anjali and Prakash, 2012; Lawania and Mathur, 2014; Singh and Singh, 2014; Dhali et al., 2016; Sharma and Singh, $2018 \mathrm{a}, \mathrm{b}$ )

- Uttarakhand (Tikader and Malhotra, 1980; Biswas and Biswas, 2010; Gupta and Siliwal, 2012)

-West Bengal (Tikader, 1966; Tikader and 
Malhotra, 1980; Biswas and Biswas, 1992, 2004, 2006; Biswas and Majumder, 1995; Majumder, 2004 a, 2005; Majumder and Talukdar, 2013; Dhali et al., 2012, 2016, 2017; Sengupta et al., 2014; Sen et al., 2015)

Elsewhere: Bangladesh, Caucasus, Central Asia, Europe, Indonesia; Japan, Macaronesia, Middle East, North Africa, Pakistan, Philippines, Southern China

\section{Wadicosa ghatica Kronestedt, 2017*}

- Karnataka (Kronestedt, 2017)

- Kerala (Kronestedt, 2017)

163. Wadicosa prasantae Ahmed et al., 2014*

- Assam (Ahmed et al., 2014; Dhali et al., 2016)

164. Wadicosa quadrifera (Gravely, 1924)

Syn. Lycosa quadrifer Gravely, 1924

- Karnataka (Gravely, 1924; Tikader and Malhotra, 1980; Dhali et al., 2016)

- Kerala (Tikader and Malhotra, 1980; Kronestedt, 1993, 2017; Patel, 2003 a; Sunil Jose et al., 2008; Adarsh and Nameer, 2016; Dhali et al., 2016)

- Maharashtra (More and Sawant, 2013)

- Rajasthan (Malhotra et al., 2019)

- Tamil Nadu (Gravely, 1924; Tikader and Malhotra, 1980; Dhali et al., 2016; Karthikeyani et al., 2017; Caleb, 2020 a)

- Uttarakhand (Biswas and Biswas, 2010)

Elsewhere: Sri Lanka

165. Zoica puellula (Simon, 1898)

Syn. Flanona puellula Simon, 1898

- Kerala (Sankaran and Sebastian, 2017)
- Maharashtra (More and Sawant, 2013)

- West Bengal (Majumder, 2004 a, 2005, 2007)

Elsewhere: Sri Lanka

\section{Checklist of Wolf Spiders (Lycosidae) in Indian States}

- Andhra Pradesh: Draposa atropalpis, Draposa burasantiensis, Draposa lyrivulva, Draposa subhadrae, Evippa rajasthanea, Evippa rubiginosa, Hippasa agelenoides, Hippasa greenalliae, Hippasa olivacea, Hippasa pisaurina, Hippasa valiveruensis, Hogna himalayensis, Lycosa balaramai, Lycosa chaperi, Lycosa indagatrix, Lycosa kempi, Lycosa madani, Lycosa poonaensis, Lycosa thoracica, Pardosa gopalai, Pardosa heterophthalma, Pardosa pseudoannulata, Pardosa sumatrana, Trochosa gunturensis, Wadicosa fidelis

- Arunachal Pradesh: Draposa oakleyi, Evippa shivajii, Hippasa agelenoides, Hippasa holmerae, Hippasa partita, Lycosa bistriata, Lycosa carmichaeli, Lycosa fuscana, Lycosa indagatrix, Lycosa iranii, Lycosa kempi, Lycosa madani, Lycosa pictula, Lycosa poonaensis, Lycosa prolifica, Lycosa tista, Pardosa algoides, Pardosa heterophthalma, Pardosa mukundi, Pardosa mysorensis, Pardosa pusiola, Pardosa sumatrana, Pardosa tridentis, Wadicosa fidelis

- Assam: Evippa praelongipes, Evippa rubiginosa, Hippasa himalayensis, Hogna himalayensis, Lycosa carmichaeli, Lycosa kempi, Lycosa mackenziei, Lycosa nigrotibialis, Lycosa phipsoni, Lycosa thoracica, Lycosa tista, Pardosa pseudoannulata, Pardosa songosa, Pardosa sumatrana, Trochosa urbana, Wadicosa fidelis, Wadicosa prasantae

- Bihar: Arctosa khudiensis, Crocodilosa leucostigma, Draposa atropalpis, Draposa 
burasantiensis, Draposa oakleyi, Hippasa pisaurina, Hogna stictopyga, Lycosa bistriata, Lycosa mackenziei, Lycosa madani, Lycosa nigrotibialis, Ocyale pilosa, Pardosa pseudoannulata, Pardosa sumatrana, Pirata sp., Trochosa punctipes, Wadicosa fidelis

- Chhattisgarh: Arctosa himalayensis, Arctosa indica, Draposa amkhasensis, Draposa porpaensis, Hippasa agelenoides, Hippasa greenalliae, Hippasa hansae, Hippasa partita, Lycosa bistriata, Lycosa jagadalpurensis, Lycosa nigrotibialis, Lycosa poonaensis, Lycosa shaktae, Pardosa bargaonensis, Pardosa bastarensis, Pardosa jabalpurensis, Pardosa mukundi, Pardosa orcchaensis, Pardosa pusiola, Pardosa ranjani, Pardosa sumatrana, Pardosa tappaensis, Pardosa timidula, Wadicosa fidelis

- Goa: Hippasa agelenoides, Hippasa greenalliae, Hippasa olivacea, Hippasa pisaurina, Lycosa carmichaeli, Lycosa mahabaleshwarensis, Lycosa phipsoni, Lycosa tista, Pardosa sumatrana

- Gujarat: Acantholycosa sp., Arctosa indica, Arctosa khudiensis, Arctosa mulani, Draposa oakleyi, Evippa banarensis, Evippa praelongipes, Evippa rajasthanea, Evippa rubiginosa, Evippa shivajii, Evippa sohani, Hippasa agelenoides, Hippasa greenalliae, Hippasa holmerae, Hippasa loundesi, Hippasa lycosina, Hippasa madhuae, Hippasa madraspatana, Hippasa olivacea, Hippasa partita, Hippasa pisaurina, Lycosa bistriata, Lycosa chaperi, Lycosa geotubalis, Lycosa goliathus, Lycosa grahami, Lycosa iranii, Lycosa lambai, Lycosa mackenziei, Lycosa madani, Lycosa mahabaleshwarensis, Lycosa moulmeinensis, Lycosa nigrotibialis, Lycosa phipsoni, Lycosa pictula, Lycosa poonaensis, Lycosa prolifica, Lycosa tista, Lycosa wroughtoni, Margonia himalayensis, Pardosa alii, Pardosa fletcheri, Pardosa heterophthalma, Pardosa minuta, Pardosa mukundi, Pardosa mysorensis, Pardosa pseudoannulata, Pardosa pusiola, Pardosa pusiola, Pardosa rhenockensis, Pardosa shyamae, Pardosa sumatrana, Pardosa sutherlandi, Pardosa timidula, Pardosa tridentis, Trochosa sp., Wadicosa fidelis

- Haryana: Hippasa haryanensis, Pardosa tikaderi, Lycosa mackenziei, Pardosa sumatrana, Wadicosa fidelis

- Himachal Pradesh: Arctosa sp., Evippa sohani, Evippa solanensis, Hippasa himalayensis, Lycosa nigrotibialis, Pardosa chambaensis, Pardosa fletcheri, Pardosa minuta, Pardosa sumatrana, Wadicosa fidelis

- Jharkhand: Lycosa carmichaeli, Lycosa mahabaleshwarensis, Wadicosa fidelis

- Karnataka: Arctosa sp., Crocodilosa leucostigma, Draposa atropalpis, Draposa burasantiensis, Draposa oakleyi, Evippa rubiginosa, Hippasa agelenoides, Hippasa greenalliae, Hippasa himalayensis, Hippasa holmerae, Hippasa lycosina, Hippasa olivacea, Hippasa pisaurina, Hogna himalayensis, Lycosa bistriata, Lycosa chaperi, Lycosa indagatrix, Lycosa mackenziei, Lycosa madani, Lycosa nigrotibialis, Lycosa phipsoni, Lycosa pictula, Lycosa prolifica, Lycosa tista, Pardosa altitudis, Pardosa mysorensis, Pardosa partita, Pardosa pseudoannulata, Pardosa pusiola, Pardosa shyamae, Pardosa songosa, Pardosa sumatrana, Trochosa punctipes, Wadicosa fidelis, Wadicosa ghatica, Wadicosa quadrifera

- Kerala: Arctosa khudiensis, Crocodilosa leucostigma, Draposa amkhasensis, Draposa atropalpis, Draposa lyrivulva, Draposa oakleyi, Evippa banarensis, Hippasa agelenoides, 
Hippasa greenalliae, Hippasa himalayensis, Hippasa holmerae, Hippasa lycosina, Hippasa olivacea, Hippasa pisaurina, Hogna himalayensis, Lycosa barnesi, Lycosa bistriata, Lycosa carmichaeli, Lycosa mackenziei, Lycosa madani, Lycosa phipsoni, Lycosa poonaensis, Lycosa tista, Lysania prolixa, Ovia procurva, Pardosa chambaensis, Pardosa kupupa, Pardosa minuta, Pardosa mysorensis, Pardosa pseudoannulata, Pardosa rhenockensis, Pardosa shyamae, Pardosa sumatrana, Trochosa punctipes, Wadicosa fidelis, Wadicosa ghatica, Wadicosa quadrifera, Zoica puellula

- Madhya Pradesh: Arctosa himalayensis, Arctosa indica, Arctosa sandeshkhaliensis, Draposa amkhasensis, Evippa jabalpurensis, Evippa mandlaensis, Hippasa agelenoides, Hippasa charamaensis, Hippasa fabreae, Hippasa greenalliae, Hippasa hansae, Hippasa olivacea, Hippasa partita, Hippasa pisaurina, Hippasa wigglesworthi, Lycosa bistriata, Lycosa jagadalpurensis, Lycosa madani, Lycosa nigrotibialis, Lycosa poonaensis, Lycosa shahapuraensis, Lycosa shaktae, Lycosa tista, Lycosa wroughtoni, Ocyale kalpiensis, Pardosa altitudis, Pardosa balaghatensis, Pardosa jabalpurensis, Pardosa kalpiensis, Pardosa mukundi, Pardosa oriens, Pardosa partita, Pardosa pseudoannulata, Pardosa pusiola, Pardosa ranjani, Pardosa rhenockensis, Pardosa sumatrana, Trochosa sp., Wadicosa fidelis

- Maharashtra: Acantholycosa lignaria, Agalenocosa subinermis, Arctosa himalayensis, Arctosa indica, Arctosa lesserti, Arctosa littoralis, Arctosa mulani, Arctosa sandeshkhaliensis, Crocodilosa leucostigma, Crocodilosa maindroni, Draposa lyrivulva, Draposa subhadrae, Evippa banarensis, Evippa jabalpurensis, Evippa mandlaensis, Evippa shivajii, Evippa sohani, Evippomma evippinum,
Geolycosa carli, Geolycosa charitonovi, Hippasa agelenoides, Hippasa charamaensis, Hippasa greenalliae, Hippasa hansae, Hippasa holmerae, Hippasa lycosina, Hippasa madhuae, Hippasa olivacea, Hippasa pisaurina, Hogna himalayensis, Hogna stictopyga, Lycosa balaramai, Lycosa barnesi, Lycosa bhatnagari, Lycosa bistriata, Lycosa choudhuryi, Lycosa fuscana, Lycosa geotubalis, Lycosa goliathus, Lycosa indagatrix, Lycosa iranii, Lycosa jagadalpurensis, Lycosa lambai, Lycosa madani, Lycosa mahabaleshwarensis, Lycosa masteri, Lycosa nigrotibialis, Lycosa phipsoni, Lycosa pictula, Lycosa poonaensis, Lycosa prolifica, Lycosa shahapuraensis, Lycosa shaktae, Lycosa shillongensis, Lycosa thoracica, Lycosa tista, Pardosa altitudis, Pardosa balaghatensis, Pardosa bargaonensis, Pardosa duplicata, Pardosa jabalpurensis, Pardosa minuta, Pardosa mukundi, Pardosa oriens, Pardosa partita, Pardosa pseudoannulata, Pardosa ranjani, Pardosa sumatrana, Pardosa sutherlandi, Pardosa timidula, Schizocosa sp., Trochosa gunturensis, Trochosa punctipes, Trochosa urbana, Wadicosa fidelis, Wadicosa quadrifera, Zoica puellula

- Manipur: Draposa atropalpis, Draposa burasantiensis, Hippasa greenalliae, Hippasa holmerae, Hippasa lycosina, Hippasa partita, Hippasa pisaurina, Hogna himalayensis, Lycosa barnesi, Lycosa bistriata, Lycosa iranii, Lycosa kempi, Lycosa madani, Lycosa shillongensis, Lycosa tista, Margonia himalayensis, Pardosa minuta, Pardosa pseudoannulata, Pardosa rhenockensis, Pardosa sumatrana, Pardosa timidula, Wadicosa fidelis

- Meghalaya: Arctosa khudiensis, Arctosa mulani, Evippa banarensis, Evippa praelongipes, Hippasa himalayensis, Hippasa lycosina,Hippasa madraspatana, Hogna himalayensis, Lycosa barnesi, Lycosa 
carmichaeli, Lycosa geotubalis, Lycosa iranii, Lycosa kempi, Lycosa mackenziei, Lycosa nigrotibialis, Lycosa shillongensis, Margonia himalayensis, Ocyale pilosa, Pardosa heterophthalma, Pardosa minuta, Pardosa pseudoannulata, Pardosa sumatrana, Pardosa sutherlandi, Shapna pluvialis, Wadicosa fidelis

- Mizoram: Draposa amkhasensis, Draposa oakleyi, Hippasa olivacea, Hippasa partita, Lycosa poonaensis, Lycosa shillongensis, Lycosa tista, Pardosa pseudoannulata, Pardosa rhenockensis, Wadicosa fidelis

- Odisha: Arctosa sp., Crocodilosa leucostigma, Draposa atropalpis, Draposa burasantiensis, Draposa lyrivulva, Draposa oakleyi, Evippa sp., Geolycosa sp., Hippasa agelenoides, Hippasa greenalliae, Hippasa partita, Hogna lenta, Lycosa iranii, Lycosa mackenziei, Lycosa madani, Lycosa phipsoni, Lycosa prolifica, Ocyale pilosa, Pardosa heterophthalma, Pardosa mukundi, Pardosa pseudoannulata, Pardosa sumatrana, Wadicosa fidelis

- Punjab: Draposa oakleyi, Evippa praelongipes, Hippasa agelenoides, Hippasa haryanensis, Hogna stictopyga, Lycosa bhatnagari, Lycosa chaperi, Lycosa mackenziei, Lycosa prolifica, Lycosa wroughtoni, Pardosa fletcheri, Pardosa pseudoannulata, Wadicosa fidelis

- Rajasthan: Anoteropsis hilaris, Arctosa indica, Draposa atropalpis, Evippa banarensis, Evippa praelongipes, Evippa rajasthanea, Hippasa agelenoides, Hippasa madhuae, Hippasa partita, Hippasa pisaurina, Lycosa bistriata, Lycosa mackenziei, Lycosa madani, Lycosa pictula, Lycosa tista, Pardosa heterophthalma, Pardosa pseudoannulata, Pardosa pusiola, Pardosa songosa, Pardosa sumatrana, Trochosa punctipes, Trochosa urbana, Wadicosa fidelis, Wadicosa quadrifera
- Sikkim: Hippasa greenalliae, Lycosa carmichaeli, Lycosa kempi, Lycosa nigrotibialis, Lycosa tista, Pardosa fletcheri, Pardosa kupupa, Pardosa rhenockensis, Pardosa shyamae

- Tamil Nadu: Arctosa lesserti, Crocodilosa leucostigma, Draposa amkhasensis, Draposa atropalpis, Draposa burasantiensis, Draposa lyrivulva, Draposa oakleyi, Evippa rubiginosa, Geolycosa carli, Hippasa agelenoides, Hippasa greenalliae, Hippasa himalayensis, Hippasa loundesi, Hippasa lycosina, Hippasa madraspatana, Hippasa olivacea, Hippasa pisaurina, Hogna himalayensis, Lycosa barnesi, Lycosa bistriata, Lycosa chaperi, Lycosa geotubalis, Lycosa indagatrix, Lycosa mahabaleshwarensis, Lycosa tista, Pardosa heterophthalma, Pardosa mukundi, Pardosa partita, Pardosa pseudoannulata, Pardosa pusiola, Pardosa sumatrana, Pardosa vagula, Trochosa punctipes, Wadicosa fidelis, Wadicosa quadrifera

- Telangana: Draposa atropalpis, Hippasa agelenoides, Hippasa olivacea, Lycosa nigrotibialis, Pardosa pseudoannulata, Pardosa sumatrana, Wadicosa fidelis

- Tripura: Hippasa greenalliae, Hippasa holmerae, Lycosa mackenziei, Lycosa phipsoni, Ocyale pilosa, Pardosa heterophthalma, Pardosa sumatrana, Pardosa sutherlandi, Wadicosa fidelis

- Uttar Pradesh: Arctosa himalayensis, Arctosa indica, Evippa solanensis, Hippasa agelenoides, Hippasa greenalliae, Hippasa himalayensis, Hippasa holmerae, Hippasa partita, Hippasa pisaurina, Hogna himalayensis, Lycosa carmichaeli, Lycosa mackenziei, Lycosa pictula, Lycosa prolifica, Lycosa tista, Pardosa fletcheri, Pardosa kupupa, Pardosa minuta, Pardosa 
pseudoannulata, Pardosa songosa, Pardosa sumatrana, Pardosa timidula, Trochosa himalayensis, Trochosa punctipes, Trochosa urbana, Wadicosa fidelis

- Uttarakhand: Arctosa himalayensis, Arctosa indica, Arctosa khudiensis, Arctosa mulani, Draposa atropalpis, Draposa burasantiensis, Draposa lyrivulva, Draposa oakleyi, Evippa rajasthanea, Evippa sohani, Hippasa agelenoides, Hippasa greenalliae, Hippasa holmerae, Hippasa loundesi, Hippasa lycosina,Hippasa madraspatana, Hippasa olivacea, Hippasa pisaurina, Hogna himalayensis, Hogna stictopyga, Lycosa carmichaeli, Lycosa chaperi, Lycosa fuscana, Lycosa iranii, Lycosa lambai, Lycosa madani, Lycosa mahabaleshwarensis, Lycosa nigrotibialis, Lycosa phipsoni, Lycosa pictula, Lycosa prolifica, Lycosa shillongensis, Lycosa tista, Pardosa algoides, Pardosa altitudis, Pardosa fletcheri, Pardosa heterophthalma, Pardosa kupupa, Pardosa minuta, Pardosa mukundi, Pardosa pseudoannulata, Pardosa rhenockensis, Pardosa shyamae, Pardosa songosa, Pardosa sumatrana, Pardosa tridentis, Trochosa himalayensis, Trochosa punctipes, Wadicosa fidelis, Wadicosa quadrifera

- West Bengal: Arctosa himalayensis, Arctosa indica, Arctosa khudiensis, Arctosa mulani, Arctosa sandeshkhaliensis, Crocodilosa leucostigma, Draposa amkhasensis, Draposa atropalpis, Draposa burasantiensis, Draposa lyrivulva, Draposa oakleyi, Evippa praelongipes, Hippasa agelenoides, Hippasa greenalliae, Hippasa himalayensis, Hippasa holmerae, Hippasa madhuae, Hippasa madraspatana, Hippasa olivacea, Hippasa partita, Hippasa pisaurina, Hogna himalayensis, Hogna stictopyga, Lycosa arambagensis, Lycosa bistriata, Lycosa carmichaeli, Lycosa chaperi, Lycosa choudhuryi, Lycosa indagatrix, Lycosa kempi, Lycosa mackenziei, Lycosa madani, Lycosa mahabaleshwarensis, Lycosa masteri, Lycosa nigrotibialis, Lycosa phipsoni, Lycosa pictula, Lycosa poonaensis, Lycosa shillongensis, Lycosa tista, Margonia himalayensis, Ocyale pilosa, Ovia procurva, Oviaquinquedens, Pardosa alii, Pardosa chambaensis, Pardosa debolinae, Pardosa duplicate, Pardosa heterophthalma, Pardosa kupupa, Pardosa minuta, Pardosa mukundi, Pardosa mysorensis, Pardosa pseudoannulata, Pardosa pusiola, Pardosa rhenockensis, Pardosa shyamae, Pardosa songosa, Pardosa suchismitae, Pardosa sumatrana, Pardosa sutherlandi, Pardosa tridentis, Trochosa punctipes, Wadicosa fidelis, Zoica puellula

\section{Chcklist of Wolf Spiders (Lycosidae) in Union Territories of India}

- Andaman \& Nicobar Islands: Draposa nicobarica, Draposa nicobarica, Pardosa sumatrana, Pardosa thalassia, Wadicosa fidelis

- Delhi: Hippasa lycosina, Lycosa iranii, Wadicosa fidelis

- Jammu and Kashmir: Acantholycosa baltoroi, Alopecosa sp., Arctosa himalayensis, Arctosa indica, Arctosa sandeshkhaliensis, Evippa sp., Evippomma evippiforme, Hippasa agelenoides, Hippasa flavicoma, Hippasa greenalliae, Hippasa himalayensis, Hippasa holmerae, Hogna rubromandibulata, Lycosa geotubalis, Lycosa mackenziei, Pardosa algoides, Pardosa alii, Pardosa altitudis, Pardosa condolens, Pardosa flavisterna, Pardosa fletcheri, Pardosa fuscula, Pardosa haupti, Pardosa hydaspis, Pardosa minuta, Pardosa pseudoannulata, Pardosa stellata, Pardosa sutherlandi, Pardosa tridentis, Pardosa vindicata, Schizocosa concolor, Trochosa propinqua, Trochosa terricola, Wadicosa fidelis 
- Ladakh: Hogna irascibilis, Pardosa algoides, Pardosa alii

\section{- Puducherry: Lycosa indagatrix}

\section{References}

Adarsh CK and Nameer PO. (2015) Spiders of Kerala Agricultural University Campus, Thrissur, Kerala, India. J Threatened Taxa 7: 8288-8295.

Adarsh CK and Nameer PO. (2016) A preliminary checklist of spiders (Araneae: Arachnida) in Chinnar Wildlife Sanctuary, Western Ghats, India. J Threatened Taxa 8: 8703-8713.

Agrawal VC and Ghose RK. (1995) Fauna of Conservation Areas No. 8: Fauna of Palamau Tiger Reserve, Zoologivcal Survey of India, Kolkata, pp 83103.

Ahmed M, Anam J, Saikia MK, Manthen SV and Saikia PK. (2014) New records spider species under Wadicosa genus (Sub-order: Araneae; Family: Lycosidae) from agricultural field of Sonitpur District, Assam, India. J New Biol Rep. 3: 60-65.

Anitha G and Vijay J. (2016) Quantification of the abundance and diversity of predatory spiders in rice ecosystem of Rajendranagar, Telangana, India. J Appl Nat Sci. 8: 1010-1014.

Anjali and Prakash S. (2012) Diversity of spiders (Araneae) from semi arid habitat of Agra (India). Indian J Arachnol. 1: 66-72.

Arora P and Monga K. (1994) New species of Pardosa Koch and Hippasa Simon (Araneae: Lycosidae) from India. Haryana Agric Univ J Res. 23: 73-76.

Barrion A and Litsinger J. (1984). The spider fauna of Philippine rice agroecosystems. II. Wetland. Philippine Entomol. 6: 11-37.

Bastawade DB and Borkar M. (2008) Arachnida (orders Scorpiones, Uropygi, Amblypygi, Araneae and Phalangida). Fauna of Goa, State Fauna Series. ZSI, Kolkata 16: 211-242.

Bastawade DB and Khandal D. (2006) Arachnida: Araneae (Spiders). Fauna of Sanjay Gandhi National Park (Invertebrates) Borivali, Mumbai (Maharashtra), Conservation Area Series. ZSI, Kolkata 26: 139-184.

Bastawade DB. (2008 a) Arachnida: Scorpionida. Araneae and Opiliones. Fauna of Lonar Wildlife Sanctuary. Conservation Area Seri es, ZSI, Kolkata 37: 133-153.
Bastawade DB. (2008 b) Arachnida: Araneae. Fauna of Pin Valley National Park. Cons ervation Area Series. ZSI, Kolkata 34: 37-44.

Basumatary P and Brahma D. (2017) Checklist of spiders from Chakrashila Wildlife Sanctuary, Assam, India. Int J Zool St. 2: 22-26.

Bennett R, Blagoev G and Copley C. (2019) Araneae of Canada. in The Biota of Canada- A Biodiversity Assessment. Part 1: The Terrestrial Arthropods (eds. Langor DW and Sheffield CS). ZooKeys 819: 41-56.

Bhandari R and Gajbe P. (2001) D escription of four new species of spiders of the families Uloboridae, Philodromidae, Gnaphosidae and Lycosidae (Arachnida: Araneae) from Madhya Pradesh, India. Rec Zool Surv India 99: 87-93.

Bhat PS, Srikumar KK and Raviprasad TN. (2013) Seasonal diversity and status of spiders (Arachnida: Araneae) in cashew ecosystem. World Appl Sci J. 22:763-770.

Bhatt N. (2014) A preliminary systematic study of spiders of major wetlands of Anand-Kheda district, Gujarat, India. Int Res J Biol Sci. 3: 71-73.

Bhattacharya A, Chetri M and Sarkar P. (2017) Spider diversity in different habitats at Jaintia Hills of Meghalaya. Int J Life Sci. 5: 613-619.

Biswas B and Biswas K. (1992) Araneae: Spiders. State Fauna Seri es 3: Fauna of West Bengal, ZSI, Kolkata 3: 357-500.

Biswas B and Biswas K. (2006) Aran eae: Spiders. State Fauna Series, Fauna of Arunachal Pradesh, ZSI, Kolkata 13: 491-518.

Biswas B and Biswas K. (2007) Araneae: Spiders. State Fauna Series, Fauna of Mizoram, ZSI, Kolkata 14: 455-475.

Biswas B and Biswas K. (2010) Araneae: Spider, Fauna of Uttarakhand, State Fauna Series, ZSI, Kolkata 18: 243-282.

Biswas B and Majumder SC. (1995) Araneae: Spider. Fauna of Meghalaya, State Fauna Series, ZSI, Kolkata 4: 93-128.

Biswas B and Majumder SC. (2000) Arachnida: Araneae. Fauna of Tripura (Arachnida: Araneae), State Fauna Series, ZSI, Kolkata 7: 113-122.

Biswas B. (1987) Araneae: Spiders (Families: Araneidae, Gnaphosidae and Salticidae). State Fauna Series, Fauna of Orissa, ZSI, Kolkata 1: 257-272.

Biswas BK and Biswas K. (2004) Araneae: Spiders. Fauna of Manipur, State Fauna Series. ZSI, Kolkata 10: $25-46$. 
Blackwall J. (1867) Descriptions of several species of East Indian spiders, apparently to be new or little known to arachnologists. Ann Mag Nat Hist. 19: 387 394.

Caleb JTD and Karthikeyani R. (2020) JoTT Checklist of the spiders of Tamil Nadu (v1.0), 10 February 2020.

Caleb JTD and Sankaran PM. (2021) Araneae of India, version 2021. https://indianspiders.in/ retrieved on March 31, 2021.

Caleb JTD. (2020 a) Spider (Arachnida: Araneae) fauna of the scrub jungle in the Madras Christian College campus, Chennai, India. J Threatened Taxa 12: 15711-15766.

Caleb JTD. (2020 b) Spi ders (Arachnida: Araneae) from the vicinity of Araabath Lake, Chennai, India. J Threatened Taxa 12: 15186-15193.

Caporiacco L. (1935) Aracnidi dell'Himalaia e del Karakoram, raccolti dalla Missione italiana al Karakoram (1929-VII). Mem Soc Ent Italiana, Genova 13: 161-263.

Cardoso P. (2014) Hogna ingens. The IUCN Red List of Threatened Species 2014: e.T58048571A58061 007.

Chauhan R, Sihag V and Singh NP. (2009) Distribution and biocontrol potential of chosen spiders. J Biopest. 2: 151-155.

Chetia P and Kalita DK. (2012) Diversity and distribution of spiders from Gibbon Wildlife Sanctuary, Assam, India. Indian J Arachnol. 1: 130142.

Chetry A and Moran J. (2019) Diversity of Namsai District, Arunachal Pradesh, India. Int J Basic Appl Res. 9: 343-351.

Choudhury SR, Siliwal M and Das SK. (2019) Spiders of Odisha: a preliminary checklist. J Threatened Taxa 11: $14144-14157$.

Chowdhury S, Boopathi Bhattacharjee TB, Dey JK and Bhattacharjee J. (2017) Diversity of predatory spider and their species composition in rice ecosystem in Kolasib district of Mizoram. Innov Farm. 2: 12-18.

Das S, Bhattacharjee R and Saikia PK. (2015) Comprehensive checklist of diurnal spider diversity in Guwahati metropolitan area, Kamrup, Assam. Trop Zool. 5: 121-131.

Deshmukh US and Tekade AP. (2019) A report on the diversity of spider fauna from Charghad river basin of Morshi, Amravati India. Biosci Biotech Res Comm. 12: 809-813.
Deshpande A and Paul R. (2016) Preliminary study on spiders of Gulbarga, Karnataka State. Int J Environ Agric Biotech. 1: 680-686.

Dey A, Debnath S, Debbarma B and Chaudhuri PS. (2013) A preliminary study on spider diversity from a hous ehold garden (artificial mixed plantation) in West Tripura, India. J Res Biol. 3:1009-1017.

Dhali DC, Roy TK, Sen S, Saha S and Raychaudhuri D. (2012) Wolf spiders (Araneae: Lycosidae) of the reserve forests of Dooars, West Bengal, India. Munis Ent Zool. 7: 1199-1213

Dhali DC, Saha S and Raychaudhuri D. (2017) Litter and ground dwelling spiders (Araneae: Arachnida) of reserve forests of Dooars, West Bengal (Monograph). World Sci News 63: 1-242.

Dhali DC, Sureshan PM and Chandra K. (2016) Indian Lycosoidea Sundevall (Araneae: Opisthothelae: Araneomorphae) in different states and union territories including an annotated checklist. World Sci News 47: 298-317.

Dharmaraj J, Gunasekaran C and Rajkumar V. (2018) Diversity and plethora of spider fauna at different habitats of the Nilgiris, Tamil Nadu, south India. Int J Rec Sci Res. 9: 24634-24637.

Ekka A and Kujur R. (2015) Spider diversity of Ram Jharna, Raigarh district, Chhattisgarh, India. Res J Pharm Tech. 8: 813-819.

Fernandes S and Ganesh S. (2020) Study on the diversity of spiders (Order: Araneae) of Lalbagh Botanical Garden and Tavarekere Park, Bangalore South. J Env Agric Biotech. 5: 275-281.

Foelix RF. (2011) Biology of Spiders, 3rd edn. Oxford University Press, New York, NY, USA, pp. 432.

Gajbe P. (2003) Checklist of spiders (Arachnida: Araneae) of Madhya Pradesh and Chhattisgarh. Zoos' Print J. 18: 1223-1226.

Gajbe P. (2004) Fauna of protected areas - 11. Spiders of Pench Tiger Reserve, Madhya Pradesh. Zoos' Print J. 19: 16-24.

Gajbe PU. (2004) Spiders of Jabalpur, Madhya Pradesh (Arachnida: Araneae). Rec Zool Surv India, Occ. Paper No. 227: 1-154.

Gajbe UA and Gajbe P. (1999 a) On three new species of spiders of the genus Hippasa Simon (Araneae: Lycosidae) from Jabalpur, Madhya Pradesh, India. Rec Zool Surv India 97: 23-28.

Gajbe UA and Gajbe P. (1999 b) A new species of spider of the genus Pardosa Koch (Araneae: Lycosidae) from Madhya Pradesh. Rec Zool Surv India 97: 95-97. 
Gajbe UA and Sharma HS. (1994) On some spiders (Araneae: Arachnida) from Bastar district (Madhya Pradesh) India. Rec Zool Surv India 94: 233-245

Gajbe UA and Singh RK. (1994) On some spiders (Araneae: Arachnida) from Kanha National Park (Madhya Pradesh), India. Rec Zool Surv India 94: 253-263.

Gajbe UA. (1995) Arachnida: Spiders. Fauna of conservation area. Fauna of Indravati Tiger Reserve (Arachnida: spiders). ZSI Kolkata 6: 53-56.

Gajbe UA. (2004) Studies on some spiders of the family Lycosidae (Araneae: Arachnida) from Madhya Pradesh, India. Rec Zool Surv India Occ. Paper 221: $1-40$.

Gajbe UA. (2007) Araneae: Arachnida. Fauna of Madhya Pradesh (including Chhattisgarh), State Fauna Series. ZSI Kolkata 15: 419-540.

Ganesh Kum ar M and Velusamy R. (1996) Composition of spider in rice ecosystem of Tamil Nadu. Madras Agric J. 83: 448-451.

Ghosh N, Biswas R and Mitra A. (2018) Species diversity, abundance and habitat association of spiders with relation to their guild composition in different habitats of North Bengal Wild Animals Park (Bengal Safari). Int J Life Sci. 6: 911-918.

Goswami TN, Kumari K, Anil and Kole B. (2015) Quantitative estimation of spider fauna in rice ecosystem of Zone IIIA in Bihar. Env Ecol. 33: 783785.

Gravely FH. (1921) The spiders and scorpions of Barkuda Island. Rec Indian Mus Calcutta 22: 399421.

Gravely FH. (1924) Some Indian spiders of the family Lycosidae. Rec Indian Mus Calcutta 26: 587-613.

Gupta N and Siliwal M. (2012) A checklist of spiders (Arachnida: Araneae) of Wildlife Institute of India campus, Dehradun, Uttarakhand, India. Indian J Arachnol. 1: 73-91.

Hadole P, Kamble S, Manthen S and Bodkhe A. (2015) Precinctive spider species in India. Indian J Arachnol. 4: 64-130.

Halarnkar MM and Pai IK. (2018) Distribution, diversity and ecology of spider species at two different habitats. Int J Env Sci Nat Res. 8: 162-167.

Hippa H and Lehtinen PT. (1983) The Zantheres group of Zoicinae (Araneae, Lycosidae) and a relimitation of the subfamily. Ann Zool Fenn. 20: 151-156.

Hore U and Uniyal VP. (2008 a) Effect of prescribed fire on spider assemblage in Terai grasslands, India. Turkish J Arachnol. 1: 15-36.
Hore U and Uniyal VP. (2008 b) Diversity and composition of spider assemblages in five vegetation types of the Terai Conservation Area, India. J Arachnol. 36: 251-258.

Hore U and Uniyal VP. (2008 c) Use of spiders (Araneae) as indicator for monitoring of habitat conditions in Tarai Conservation Area, India. Indian Forester 134: 1371-1380.

Hore U. (2009) Diversity and structure of spider assemblages in Terai Conservation area. Ph.D. Thesis, Saurashtra University, Rajkot, Gujarat, India.

Huang X, Quan X, Wang X, Yun Y and Peng Y. (2018) Is the spider a good biological control agent for Plutella xylostella (Lepidoptera: Plutellidae)? Zoologia 35: e23481.

Isaia M and Mammola S. (2018) Vesubia jugorum. The IUCN Red List of Threatened Species 2018: e.T98700253A98700319.

Jangid AK, Dewasi SR, Kumar L, Yadav D, Sharma V and Upadhyay M. (2019) Diversity of spiders (Arachnida: Araneae) from central Aravalli Range, Rajasthan. Serket 17: 61-67.

Joseph AR and Premila KS. (2016) A study on the richness of spider fauna in rice Ecosystem. J Ent Zool St. 4: 425-430.

Joseph MM, Paul J, Sankaran PM and Sebastian PA. (2017) Preliminary results on the spider fauna (Arachnida: Araneae) of the high altitude Shola ecosystem in the Western Ghats. Proc Nat Conf Ecol Sust Dev Wildlife Cons. Pp. 41-49.

Kananbala A, Bhubaneshwari M and Siliwal M. (2018) A checklist of spiders (Arachnidae: Araneae) of Manipur, India with some first records and a new species Conothele khunthokhanbi (Family: Ctenizidae). J Ent Zool St. 6: 2209-2214.

Kapoor V. (2008) Effects of rainforest fragmentation and shade-coffee plantations on spider comm unities in the Western Ghats, India. J Insect Cons. 12: 53-68.

Karthikeyani R, Caleb JTD, Gajbe UA and Muthuchelian K. (2017) Checklist of spiders (Arachnida: Araneae) of the State of Tamil Nadu, India. Munis Ent Zool. 12: 180-193.

Karthikeyani R. (2013) Biodiversity of spiders (Araneae) in Kumbakarai Falls, Periyakulam Taluk, Theni District, Tamil Nadu, So uth India. Ph.D. Thesis, Madurai Kamaraj University, Madurai, India, pp 288.

Kashmeera NA, Drisya-Mohan OM and Sudhikumar AV. (2020) Spiders of rocky desert in Kailana, Rajasthan, India. Serket 17: 201-206. 
Kaur M, Das SK, Anoop KR and Siliwal M. (2014) Preliminary checklist of spiders of Keoladeo National Park, Bharatpur, Rajas than with first record of Ptocasius strupifer Simon, 1901 (Araneae: Salticidae) from India. Munis Ent Zool. 9: 501-509.

Keswani S and Vankhede G. (2014) Diversity, population and habitat used by spiders in bananaagro-ecosystem. Indian J Arachnol. 3: 12-27.

Keswani S. (2014) Diversity, population and microhabitat used by spiders in citrus agroecosystem. Indian J Arachnol. 3: 90-101.

Khan AA and Misra DS. (2003) Studies on qualitative and quantitative composition of spider fauna in rice ecosystem of eastern Uttar Pradesh. Plant Prot Bull. 55: 35-41.

Khan AA and Rather AQ. (2012) Diversity and foraging behaviour of spiders (Arachnida: Araneae) in the temperate maize ecosystem of Kashmir. J Biol Cont. 26: 179-189.

Khan AA. (2006) Relative abundance of spider fauna of rice ecosystem. SAARC J Agric. 4: 159-166.

Khan AA. (2009) Biodiversity of spider fauna (Arachnida: Araneae) in horticultural ecosystem of Kashmir. Indian J Ecol. 36: 59-64.

Khan AA. (2011) Spider fauna (Arachnida: Araneae) in temperate fruit orchards of Kashmir. J Biol Cont. 25: 103-113.

Kokilamani AL, Lokeshkumar P, Rakesh BO, Sahana R and Geetha HC. (2019) A preliminary study on diversity of spiders from Tumkur University campus, Tumakuru, India. Int J Adv Sci Res Manag. 4: 84-87.

Kronestedt T. (1993) Species of Wadicosa (Araneae: Lycosidae): revised generic allocation of Lycosa quadrifer Gravely from Sri Lanka and India. J Nat Hist. 27: 313-321.

Kronestedt T. (2010) Draposa, a new wolf spider genus from South and Southeast Asia (Araneae: Lycosidae). Zootaxa 2637: 31-54.

Kronestedt T. (2017) Species of Wadicosa (Araneae, Lycosidae): a new species close to $W$. quadrifera (Gravely) from the Western Ghats, India. Zootaxa 4300: 295-300.

Kujur R and Ekka A. (2016) Exploring the Spider fauna of Gomarda Wildlife Sanctuary, Chhattisgarh, India. Int Res J Biol Sci. 5: 31-36.

Kumar A, Kanaujia A, Kumar A, Kumar V and Mishra H. (2017) Diversity of spiders in Kukrail Reserve Forest, Lucknow, Uttar Pradesh, India. J Env Sci Tech. 4: 42-45.
Kumar D and Shivakumar MS. (2004) Ecological stu dies on spiders in rice agroecosystem of Vadodara (Gujarat) with special emphasis on biocontrol aspect. Indian J Ent. 66: 323-327.

Kumar D and Shivakumar MS. (2006) Seasonal abundance of spiders in pigeonpea agroecosystem. Indian J Env Sci. 10: 43-46.

Kumari K. (1983) Taxonomy of spiders (Arachnida: Aranceae) from northern India. M. Phil. Thesis, Department of Zoology, Punjabi University, Patiala.

Kumari V, Saini KC and Singh NP. (2017) Diversity and distribution of spider fauna in arid and semi-arid region of Rajasthan. J Biopest. 10: 17-24.

Lanka LP, Kamble SS and Bodkhe AK. (2017) An addition to spider fauna from the vicinity of Radhanagari Wildlife Sanctuary of Kolhapur District. Int J Sci Engg Res. 5: 280-283.

Lawania KK and Mathur P. (2014) Baseline studies on the spider fauna (Araneae) of Braj region (BrajBhoomi), India. Int J Basic Appl Biol. 2: 137-141.

Lawania KK and Trigunayat MM. (2015) A comparative study of the spider (Araneae) fauna in Keoladeo National Park (KNP), Nahargarh Wildlife Sanctuary (NWS) and Sur-sarovar Bird Sanctuary (SBS), India. Int J Agric Sci. 6: 141-146.

Leardi Z. (1901) Aracnidi d'Almora. Atti Soc Ital Sci Nat Mus Civ Storia Nat Milano 40: 85-94.

Lu T, Wang LY, Hadole P and Zhang ZS. (2016) Redescription of four wolf-spiders (Araneae: Lycosidae) from India. Indian J Arachnol. 5: 130142.

Majumder SC and Talukdar S. (2013) Studies on taxo nomy and diversity of spiders from Darjeeling Hills with special reference to family Clubioneidae in light of conservation. Rec Zool Surv India Occ. Paper No. 340: 1-96.

Majumder SC. (2004 a) Taxonomic studies of some spiders from mangrove and semi-mangrove areas of Sundarban. Mem Zool Surv India 20: 1-42.

Majumder SC. (2004 b) A new species of wolf spider (Araneae: Lycosidae) from crop fields of the Sundarban Estuary, West Bengal, India. J Bombay Nat Hist Soc. 101: 121-123.

Majumder SC. (2004 c) Studies on spider fauna of coastal region of India: description of two new species of Pardosa Koch (Araneae: Lycosidae) from the coastal region of Sundarbans, West Bengal (Part1). Rec Zool Surv India 102: 97-103. 
Majumder SC. (2005) Studies on some spiders from eastern coastal region of India. Mem Zool Surv India 20: 1-57.

Malamel JJ, Sankaran PM, Joseph MM and Sebastian PA. (2015) First record of the wolf spider genus Lysania Thorell, 1890 from India with the description of a new species (Araneae: Lycosidae: Zoicinae). Zootaxa 3904: 293-297.

Malhotra GS, Neera K and Saxena MM. (2019) Spider diversity and abundance in different habitats of Upper-Northern Rajasthan. ESSENCE Int J Env Rehab Conserv. 10: 1-14.

Malik S, Das SK and Siliwal M. (2015) Spider (Arachnida: Araneae) fauna of Delhi with first report of cobweb spider Argyrodes bonadea (Karsch, 1881) from India. Indian J Arachnol. 4: 31-36.

Malik V and Goyal V. (2017) Biodiversity of spiders in different habitats of Western Haryana, India. J Ent Zool St. 5: 822-825.

Marshall AD and Martin KA. (2011) Correlated morphological, ecological, and behavioral aspects of the microhabitat associations in Geolycosa wolf spiders of Florida (Araneae: Lycosidae). South Nat. 10: 357-364.

Marusik YM, Ballarin F, Omelko MM and Koponen S. (2014) On new and interesting records of spiders from northern Pakistan and India (Aranei). Arthropoda Selecta 23: 415-424.

Mathew EV, Sudhikumar A and Sebastian PA. (2014) Vertical stratification of spiders in Kuttanad rice agroecosystem, Kerala. J Biol Cont. 28: 62-67.

Meshram A. (2011) Spiders (Arachnida: Araneae) from Toranmal Sanctuary, Maharashtra, India. E-Int Sci Res J. 4: 326-334.

Mishra AK and Shrivastava SK. (2002) Spiders associated with rice crop in Raipur. Agric Sci Diges t 22: 261-263.

Mohapatra AK, Biswas T and Parida SP. (2014) Spider Diversity in RIE campus. RIE, Bhubaneswar, pp.76.

More S and Sawant V. (2013) Spider fauna of Radhanagari Wildlife Sanctuary, Chandoli National Park and Koyna Wildlife Sanctuary. Indian J Arachnol. 2: 81-92.

Mubeen M and Basavarajappa S. (2018) Density, abundance and per cent occurrence of spider species (Arachnida: Araneae) in and around Mysore city, Karnataka, India - a case study. IOSR J Pharm Biol Sci. 13: 31-40.

Murphy NP, Framenau VW, Donnellan SC, Harvey MS, Park Y-C and Austin AD. (2006) Phylogenetic reconstruction of the wolf spiders (Araneae: Lycosidae) using sequences from the $12 \mathrm{~S}$ rRNA, 28S rRNA, and NADH1 genes: implications for classification, biogeography, and the evolution of web building behavior. Mol Phylogenet Evol. 38: 583-602.

Nautiyal S, Khan YDI, Kaechele H and Bhaskar K. (2017) Diversity and distribution of spiders in Gogi, Yadgi $r$ District: a semi -arid landscape in southern India. Int J Ecol Env Sci. 43: 195-204.

Nerlekar AN, Warudkar AM, Gowande GG, Salve SS, Raut A, Patankar SR and Nalavade SB. (2016) A review of the faunal diversity of the Fergusson College campus, Pune, India. Zoos' Print J. 31: 4-25.

Nyffeler M and Birkhofer K. (2017) An estimated 400800 million tons of prey are annually killed by the global spider community. Sci Nat. 104: 12.

Oppenheimer JR and Tikader BK. (1976) The ground activity of spiders (Araneae) and harvestmen (Phalangidae) in West Bengal, India. J Bombay Nat Hist Soc. 73: 121-141.

Palem H, Kanike S and Purushottam VRS. (2016) Diversity of spider fauna (Arachnida: Araneae) in different ecosystems, Eastern Ghats, southern Andhra Pradesh, India. So uth Asian J Life Sci. 4: 5160.

Palita SK. (2016) Faunal diversity assessment of invertebrates and lower vertebrates of Deomali hills of Eastern Ghats, Koraput, Odisha, India. Final Technical Report. Odisha Biodiversity Board and Central University of Orissa, pp 44.

Panda S, Mishra S, Priyadars hini D and Parida P. (2011) Spiders of Nandankanan. Forest Department, Government of Odisha, pp 64.

Pandit R and Dharwadkar M. (2020) Preliminary checklist of spider fauna (Araneae: Arachnida) of Chandranath Hill, Goa, India. J Threatened Taxa 12: 16597-16606.

Pandit R and Pai I. (2017) Spiders of Taleigao Plateau, Goa, India. J Env Sci Pub Hlth. 1: 240-252.

Parasharya BM and Pathan VA. (2013) Diversity of spider fauna in Lucerne (Medicago sativa L.). J Biol Cont. 27: 253-259.

Parmar BM and Patel KB. (2015) Preliminary study of spiders (Order: Araneae) from Taranga Hills. Int J Sci Res. 6: 23-25.

Parmar BM, Patel KB, Joshi JD and Chaudhari NR. (2015) Faunastic study of spiders diversity from islands and costal areas of gulf of Kutch, India. Life Sci. Leaflets 67: 12-23. 
Patel BH and Pillai GK. (1988) Studies on the spider fauna of groundnut fields in Gujarat, India. J Biol Cont. 2: 83-88.

Patel BH and Reddy TS. (1993) On some new species of spiders of the genera Hippasa Simon, Lycosa Latreille, Pardosa Koch and Trochosa Koch (family: Lycosidae) from coastal Andhra Pradesh, India. Rec Zool Surv India 90: 121-133.

Patel BH and Vyas R. (2001) Spider of Hingolgadh Nature Education Sanctuary, Gujarat, India. Zoos' Print J. 16: 589-590.

Patel BH. (1971) Studies on some spiders (Araneae: Arachnida) from Gujarat, India. Ph.D. Thesis submitted to Sardar Patel University, Vallabh Vidyanaga, Anand, Gujarat, India.

Patel BH. (2003 a) Fauna of protected areas - A preliminary list of spiders with the descriptions of three new species from Parambikulum Wildlife sanctuary, Kerala. Zoos' Print J. 18: 1207-1212.

Patel BH. (2003 b) Spiders of Vansada National Park, Gujarat. Zoos' Print J. 18: 1079-1083.

Patil SR, Sambath S and Bhandari R. (2013) Preliminary investigation on spiders (Arachnida: Araneae) in Rani Veerangana Durgawati Wildlife Sanctuary, Damoh, Madhya Pradesh, India. Indian Forester 139: 943-946.

Patil SR. (2012) Spiders of Jabalpur district (Arachnida: Araneae): Updated checklist 2011. Indian J Arachnol. 1: 143-149.

Phartale NN, Kadam JA and Gyananath G. (2016) First report of Geolycosa charitonovi (Mcheidze, 1997) (Araneae: Lycosidae) from India. J Ent Zool St. 4: 937-939.

Picard-Cambridge, O. (1885) Araneidea. in Scientific results of the second Yark and mission; bas ed upon the collections and notes of the late Ferdin and Stoliczka, Ph.D. Government of India, Calcutta, pp 115.

Planas E, Fernández-Montraveta C and Ribera C. (2013) Molecular systematics of the wolf spider genus Lycosa (Araneae: Lycosidae) in the Western Mediterranean Basin. Mol Phylogenet Evol. 67: 414428.

Pocock RI. (1899) Diagnoses of some new Indian Arachnida. J Bombay Nat Hist Soc. 12: 744-753.

Pocock RI. (1900) The Fauna of British India including Ceylon and Burma Arachnida. Taylor Francis London, pp 279.
Pocock RI. (1901) Descriptions of some new species of spiders from British India. J Bombay Nat Hist Soc. 13: 478-498.

Pooja A, Anil Kumar, Quasin S, Lekshmi S and Uniyal VP. (2019) Spider fauna of Navdanya Biodiversity Farm, Uttarakhand, India. Indian Forester 145: 392-397.

Prajapati DA, Patel KR, Munjpara SB, Chettiar SS and Jhala DD. (2016) Spiders (Arachnida: Araneae) of Gujarat University Campus, Ahmadabad, India with additional description of Eilica tikaderi (Platnick, 1976). J Threatened Taxa 8: 9327-9333.

Priyadarshini N, Kumari R, Pathak RN and Pandey AK. (2015) Biodiversity and community structure of spiders in Saran, part of Indo-Gangetic Plain, India. Asian J Conserv Biol. 4: 121-129.

Punjoo S and Bhat GA. (2015) First report of spiders (Arachnida: Araneae) from Dachigam National Park, Kashmir, India. Int J Res. 2: 707-719.

Quasin S and Uniyal VP. (2011) Spider diversity along altitudinal gradient in Milam Valley, Nanda Devi Biosphere Reserve, Western Himalaya. Indian Forester 137:1207-1211

Quasin S and Uniyal VP. (2013) Spiders (Araneae) in Bhyundar valley of Nanda Devi Biosphere Reserve. In: Biodiversity Communities and Climate Change (eds. Kala CP and Silori CS), The Energy and Resource Institute, TERI, New Delhi, pp 13-24.

Rajeevan S, Kunnath SM, Varghese T and Kandambeth PP. (2019) Spider diversity (Arachnida: Araneae) in different ecosystems of the Western Ghats, Wayanad Region, India. South Asian J Life Sci. 7: 29-39.

Rao KT, Bastawade DB, Javed SMM and Krishna ISR. (2005) Arachnid fauna of Nallamalai Region, Eastern Ghats, Andhra Pradesh, India. ZSI, Kolkata, Occ Paper No. 239: 1- 42.

Raychaudhuri D, Saha S and Roy T K. (2016) Spiders: a proficient candidate in practising IPM for Darjeeling Tea. World Sci News 38: 1-62.

Reimoser E. (1934) Araneae aus Süd-Indien. Rev Suis Zool. 41: 465-511.

Rithe K. (2012) Spider diversity from relocated area of Melghat Tiger Reserve. Indian J Arachnol. 1: 92-105.

Roewer CF. (1955) Katalog der Araneae von 1758 bis 1940, bzw. 1954. 2. B and, Abt. a (Lycosaeformia, Dionycha (excl. Salticiformia) 2. B and, Abt. b (Salticiformia, Cribellata) (Synonyma-Verzeichnis, Gesamtindex). Institut royal des Sci. naturelles de Belgique, Bruxelles, pp 1751. 
Rovner JS. (1980) Morphological and ethological adaptations for prey capture in wolf spiders (Araneae: Lycosidae). J Arachnol. 8: 201-215.

Sadana GL. (1969) A new species of the spider of the genus Lycosa Latreille (family: Lycosidae) from India. Sci Cult. 35: 416-418.

Sadana GL. (1972) Mechanics of copulation in Lycosa chaperi Simon (Araneida: Lycosidae). Bull Brit Arachnol Soc. 2: 87-89.

Sadana GL. (1981) Mechanics of copulation in Lycosa wroughtoni Pocock (Lycosidae: Araneida). Zool Polon. 28: 333-340.

Saha S, Biswas V and Raychaudhuri D. (1994) Heteropodidae and Lycosidae of Buxa Tiger Reserve, West Bengal. Acta Arachnol. 43: 43-48.

Saha S, Das I and Raychaudhuri D. (2017) Spider faunal diversity of Barasat and Basirhat, 24 Parganas, West Bengal, India. World News Nat Sci. 15: 49-85.

Saha S, Dhali DC and Raychaudhuri D. (2015) Spider fauna (Araneae: Arachnida) of Rajasthan with special reference to Ranthambore National Park, Rajasthan, India. Indian J Arachnol. 4: 30-40.

Saha S, Roy TK and Raychaudhuri D. (2016) Survey on spider faunal diversity of Darjeeling tea plantations. Mun Ent Zool. 11: 622-635.

Sailu G, Narayana BL, Ramaiyan D, Naresh B, Rao VV, Adepu H, Khandelwal R, Devulapalli P and Krishna P. (2017) Faunal diversity of Ameenpur Lake, Telangana state, India: A biodiversity heritage site. J Ent Zool St. 5: 512-526.

Sankaran PM and Sebastian PA. (2017) Redescription of Zoica puellula (Simon, 1898) (Araneae: Lycosidae: Zoicinae) and transfer of Zoica harduarae (Biswas and Roy, 2008) to Agelenidae C.L. Koch, 1837. Zootaxa 4276: 145-150.

Sankaran PM, Caleb JTD and Sebastian PA. (2021) Revision of Indian wolf spiders: I. Genus Arctosa C.L. Koch, 1847 (Araneae: Lycosidae, Tricassinae). Zootaxa 4908: 489-504.

Sankaran PM, Malamel JJ and Sebastian PA. (2017) On the new monotypic wolf spider genus Ovia gen. nov. (Araneae: Lycosidae, Lycosinae). Zootaxa 4221: $366-$ 376.

Saranya VSL, Samiayyan K and Prema MS. (2019) Diversity of predatory spider fauna in maize ecosystem. J Biol Cont. 33: 27-35.

Sebastian PA, Mathew MJ and Murugesan S. (2011) Spider fauna in the forest and agricultural ecosystems of central Kerala, India, in Arthropods and their Conservation in India (Insects and
Spiders) (eds. Uniyal, V.P, and Shrivastava, A.). ENVIS Bulletin: Wildlife Protected Areas 14: 159-174.

Sebastian PA, Mathew MJ, Beevi SP, Joseph J and Biju CR. (2005 a) The spider fauna of the irrigated rice ecosystem in central Kerala, India across different elevational ranges. J Arachnol. 33: 247-255.

Sebastian PA, Muruges an S, Mathew MJ, Sudhikum ar AV and, Sunish E. (2005 b) Spiders in Mangalavanam, an ecosensitive mangrove forest in Cochin, Kerala, India (Araneae). European Arachnol Acta Zool Bulg. Suppl. 1: 315-318.

Sen S, Dhali DC, Saha S and Raychaudhuri D. (2015) Spiders (Araneae: Arachnida) of Reserve Forests of Dooars: Gorumara National Park, Chapramari Wildlife Sanctuary and Mahananda Wildlife Sanctuary. World Sci. News 20: 1-339.

Sen S, Saha S and Raychaudhuri D. (2009) Spiders of Ranthambore National Park, Rajasthan. Ins ect Env. 16: $172-173$.

Sengupta A, Saha S and Raychaudhuri D. (2014) Diversity of spiders in different low lying crop fields of South 24-Parganas, West Bengal. Indian J Arachnol. 3: 17-27.

Sharma A and Singh R. (2018 a) Biodiversity and guild structure of spiders in northeastern Uttar Pradesh. Res J Life Sci Bioinf Pharm Chem Sci. 4: 525-541.

Sharma A and Singh R. (2018 b) Species diversity and guild structure of spiders from Siddharthnagar, Uttar Pradesh, India. Res J Life Sci Bioinf Pharm Chem Sci. 4: 383-390.

Sharma BD and Sharma T. (1977) Lycosid spiders feeding on juveniles of the skipper frog Rana cyanophlyctis Scfineider. J Bombay Nat Hist Soc. 74: 144-146.

Sharma S. (2014) A study on spiders as predators in the agroecosystems. Munis Ent Zool. 9: 80-83.

Sharma A, Singh G and Singh R. (2020 a) Faunal diversity of Liocranidae, Mimetidae, Miturgidae, Nesticidae and Oecobiidae (Arachnida: Araneae) of India. Serket 17: 270-283.

Sharma A, Singh G and Singh R. (2020 b) Faunal Diversity of Linyphiidae (Araneomorphae: Araneae: Arachnida) in India. Asian J Conserv Biol. 9: 304 314.

Sharma A, Singh G and Singh R. (2021) Faunal diversity of spider families Dictynidae, Dysderidae, Eresidae and Filistatidae (Araneomorphae: Araneae: Arachnida) in India. Int J Zool Appl Biosc. 6: 1-9.

Sherriffs WR. (1919) A contribution to the study of south Indian Arachnology. Ann Mag Nat Hist. 
9: 220-253.

Siddhu J, Lohani HP, Pathak G and Kaushal BR. (2020) Spider diversity in rice and mix vegetable agro bhabar region of Nainital district, Uttarakhand. Bull. Env Pharm Life Sci. 9: 101-105.

Siliwal M and Molur S. (2008) An inventory of the spider fauna of Odisha, India. Unpublished report, submitted to the Odhisa Forest Department, Bhubaneshwar. Zoo Outreach Organisation, pp 12.

Siliwal M, Suresh B and Pilo B. (2003) Spiders of Purna Wildlife Sanctuary, Dangs, Gujarat. Fauna of protected areas - 3. Zoos' Print J. 18: 1259-1263.

Siliwal M. (2000) Taxonomic studies of Spiders with special emphasis on their role in biological control of insect pests. Ph.D. Thesis, The M.S. University of Baroda, Vadodara, Gujarat, India, pp 83.

Simon E. (1884) Arachnides recueillis en Birmanie par M. le chevalier J. B. Comotto et appartenant au Musée civique d'histoire naturelle de Gènes. Ann. Mus. Civ. Storia Nat. Genova 20: 325-372.

Simon E. (1885 a) Matériaux pour servir à la faune arachnologiques de l'Asie méridionale.I.Arachnides recueillis à Wagra-Karo or près Gundacul, district de Bellary par M.M. Chaper. II. Arachnides recueillis à Ramnad, district de Madura par M.l'abbé Fabre. Bull Soc Zool Fr. 10: 1-39.

Simon E. (1885 b) Matériaux pour servir à la faune arachnologiques de l'Asie méridionale.III.Arachnides recueillis en 1884 dans la presqu'île de Malacca, par M.J. Morgan. IV. Arachnides recueillis à Collegal, district de Coimbatoore, par M.A. Theobald G.R. Bull Soc Zool Fr. 10: 436-462.

Simon E. (1897) Arachides recueillis par M.M.Maindron à Kurrachee et à Matheran (près Bombay) en 1896. Bull Mus d'Hist Nat. 3: 289-297.

Singh BB and Singh R. (2014) Incidence and biodiversity of riceland spiders (Arthropoda: Arachnida) in northeastern Uttar Pradesh, India. Indo-Amer J Life Sci Biotech. 2: 64-89.

Singh BB, Singh R and Singh G. (2020) Faunal diversity of Clubionidae, Ctenidae, Cybaeidae, Deinopidae and Desidae (Araneomorphae: Araneae: Arachnida) in India. J Appl Biosci. 46: 32-43.

Singh BB, Singh R and Singh G. (2021) Faunal diversity of spitting spiders (Scytodidae: Araneomorphae: Araneae: Arachnida) in India. World J Pharm Life Sci. 7: 82-89.

Singh J and Mavi GS. (1984) A spider as predator of Lambides boeticus (Linn.) (Lepidoptera: Lycaenidae), Punjab, India. J Bombay Nat Hist Soc. 81: 501 .
Singh R. (2021 a) Distribution of Sparassidae (Araneomorphae: Araneae: Arachnida) in India. World J Pharm Life Sci. 7: 82-89.

Singh, R. (2021 b). Faunal biodiversity of Tetragnathidae (Araneomorphae: Araneae: Arachnida) in India. Int Biol Inn. 3: 92-119.

Singh R and Singh G. (2020) Diversity of mygalomorph spiders (Aranae: Opisthothelae) in India. Int Biol Innov. 2: 178-201.

Singh R and Singh G. (2021) Updated checklist of Philodromidae (Araneae: Arachnida) from India. World J Pharm Life Sci. 7: 129-139.

Singh R, Singh G and Sharma A. (2020 a) Faunal diversity of Hahniidae, Hersiliidae and Homalonychidae (Arachnida: Araneae: Araneomorphae) in India. Serket 17: 240-251.

Singh R, Singh G and Sharma A. (2020 b) Diversity of yellow sac spiders (Cheiracanthiidae: Araneae: Arachnida) in India. J Ent Zool St. 8: 118-126

Singh R, Singh G and Singh BB. (2020 c) Diversity of simonid spiders (Araneae: Salticidae: Salticinae) in India. Int Biol Innov. 2: 247-276.

Singh R, Singh G and Singh BB. (2020 d) Diversity of Marpissoida, Chrysillini and Hasariini (Arachnida: Araneae: Salticidae: Salticinae) in India. Res J Life Sci Bioinf Pharm Chem Sci. 6: 15-42.

Singh R, Singh G and Singh BB. (2020 e) Diversity of Asemoneinae, Eupoinae, Hisponinae, Lyssomaninae, Onomastinae and Spartaeinae (Arachnida: Araneae: Salticidae) in India: A checklist and bibliography. Res J Life Sci Bioinf Pharm Chem Sci. 6:29-46.

Singh R, Singh G and Singh BB. (2020 f) Diversity of Amycoida and Astioida (Arachnida: Araneae: Salticidae: Salticinae) in India. J Ent Zool St. 8: 14781488.

Singh R, Singh G and Singh BB. (2021 a) Faunal diversity of jumping spiders (Salticidae: Araneae: Arachnida) in India. Int Biol Innov. 3: 1-37.

Singh R, Singh G and Singh BB. (2021b) Faunal diversity of Agelenidae, Amaurobiidae, Anyphaenidae, Arkyidae, Cithaeronidae and Corinnidae (Araneae: Arachnida) in India. Mun Ent Zool. 16: 772-786.

Singh S and Borkotoki A. (2014) Species diversity measure of webless spiders in four different habitats of Barpeta District, Assam, India. Indian J Appl Res. 4: 556-558.

Singh S, Borkotoki A and Sarmah CK. (2012) Species distribution of spiders in Barpeta district of Assam: a diversity measure. Int Sci Res J. 4: 47-57. 
Sinha TB. (1951) On the collection of lycosid spiders in the ZSI (Indian Museum) with critical notes on the species. Rec Indian Mus Calcutta 48: 9-52.

Sivaperuman C and Rathore NS. (2004) A preliminary report on spiders in Desert National Park, Rajasthan, India. Zoos' Print J. 19: 1485-1486.

Strand E. (1909) Süd- und ostasiatische Spinnen. II. Fam. Clubionidae. Fam. Salticidae. Abh Naturf Ges Görlitz 26: 1-128.

Sudhikumar AV, Mathew MJ, Sunish E, Murugesan S and Sebastian PA. (2005 a) Preliminary studies on the spider fauna in Mannavan shoal forest, Kerala, India (Araneae). Eur Arachnol Acta Zool Bulg Suppl. 1: 319-327.

Sudhikumar AV, Mathew MJ, Sunish E and Sebastian PA. (2005 b) Seasonal variation in spider abundance in Kuttanad rice agroecosystem, Kerala, India (Araneae). Eur Arachnol Acta Zool Bulg Suppl. 1: 181-190.

Sudhikumar AV. (2007) Studies on the taxonomy and bionomics of some predacious spiders on insect pests of rice agroecosystem in Kuttanad, Kerala. Ph.D. Thesis, Mahatma Gandhi University, Kottayam, Kerala, India. pp 232.

Sugumaran MP, Soundararajan RP and Lakshamanan V. (2007) Spider fauna in the horticultural crops of Yercaud hills. Zoos' Print J. 22: 2721-2722.

Sumesh NV and Sudhikumar AV. (2020) Checklist of spiders from the sacred groves of Northern Kerala, India. UP J Zool. 41: 104-115.

Sunil Jose K, Sudhikumar AV, Davis S and Sebastian PA. (2008) Preliminary studies on the spider fauna (Arachnida: Araneae) in Parambikulam Wildlife Sanctuary in Western Ghats, Kerala, India. J Bombay Nat Hist Soc. 105: 264-273.

Talukdar S and Majum der SC. (2008) Diversity of spider fauna of Bortibeel North 24 Parganas, West Bengal, their possible utilities as significant biological pest control in the paddy field-ecosystem. Rec Zool Surv India 108: 39-45.

Thakur JN, Singh JP, Verma OP and Diwakar MC. (1995) Spider fauna in the rice ecosystem of Jammu. J Biol Cont. 9: 125-126.

Thorell T. (1891) Spindlar från Nikobarerna och andra delar af södra Asien. Kong. Svenska Vet.-Akad Handl. 24: 1-149.

Thumar RH. (2019) Biodiversity and taxonomic study of predacious spiders of some orchard plants in and around Navsari District Gujarat. Ph.D. Thesis, Veer Narmad South Gujarat University, Surat, Gujarat, pp 261.
Tikader BK and Biswas B. (1981) Spider fauna of Calcutta and vicinity: Part-I. Rec Zool Surv India, Occ. Paper 30: 1-149.

Tikader BK and Malhotra MS. (1976) Studies on some spiders of the genus Pardosa Koch from India (family: Lycosidae). Proc Indian Acad Sci. 83: 123131.

Tikader BK and Malhotra MS. (1980) Lycosidae (Wolfspiders), Araneae. The fauna of India. ZSI Kolkata 1: 248- 447.

Tikader BK and Mukerji S. (1971) A new species of spider of the genus Lycosa (family Lycosidae) from India. Sci Cult. 37: 531.

Tikader BK. (1964) Zoological results of the Indian Cho-Oyu Expedition (1958) in Nepal. Part 8Arachnida. Rec Indian Mus Calcutta 59: 257-267.

Tikader BK. (1966) On a collection of s piders (Araneae) from the desert areas of Rajasthan (India). Rec Indian Mus Calcutta 59: 435-443.

Tikader BK. (1970) Spider fauna of Sikkim. Rec Zool Surv India 64: 1-83.

Tikader BK. (1977 a) Description of two new species of wolf-spider (family: Lycosidae) from Ladakh, India. J Bombay Nat Hist Soc. 74: 144-146.

Tikader BK. (1977 b) Studies on spider fauna of Andaman and Nicobar islands, Indian Ocean. Rec Zool Surv India 72: 153-212.

Tikader BK. (1982) Spiders: Araneae. The Fauna of India, Part-1 Family Araneidae (=Argiopidae), Typical Orb-Weavers. ZSI Kolkata, pp 1-293.

Tiwari AK and Singh R. (2021) Diversity and distribution of Pisauridae (Araneae: Araneomorphae: Arachnida) in India. Int J Ent Res. 6: 119-125.

Tiwari AK, Singh G and Singh R. (2021 a) Biodiversity of some poorly known families of spiders (Areneomorphae: Araneae: Arachnida) in India. J Global Biosci. 10: 8352-8371.

Tiwari AK, Singh G and Singh R. (2021 b) Faunal diversity of Oonopidae (Araneomorphae: Araneae: Arachnida) in India. J Global Biosci. 10: 8340-8351.

Trivedi V. (2009) Diversity of spiders in ground nut crop fields in village area of Saurashtra region. J Bombay Nat Hist Soc. 106: 184-189.

Umarani S and Umamaheshwari S. (2013) Diversity of spider fauna at different sites in Palani Hills, Dindigul district, Tamil Nadu, South India. Int J Adv Biol Res. 3: 535-539.

Uniyal VP and Hore U. (2006) Studies on the spider 
fauna in mixed sal forest area of Chandrabani, Dehradun. Indian Forester 132: 83-88.

Uniyal VP and Hore U. (2009) Effect of management practices on spider diversity in Terai Conservation Area (TCA). Final Project Report, Wild Life Institute of India, Dehradun, pp 222.

Uniyal VP, Sivakumar K and Quasin S. (2011) Diversity of spiders in Nanda D evi Biosphere Res erve. Wildlife Institute of India, Dehradun. DST Project Completion Report, pp 199.

Uniyal VP. (2006) Records of spiders from Indian transHimalayan region. Indian Forest. 132: 177-181.

Walckenaer CA. (1837) Histoire naturelle des insectes. Aptères.Tome premier. Roret, Paris, pp 682.

Wankhade VB and Manwar N. (2016) Explorative study on the diversity and characteristics of spider families. Int J ZoolRes. 6: 15-24.

White L, Pryce D, Wilkins VL and Dutton A-J. (2019 a) Dolocosa dolosa. The IUCN Red List of Threatened Species 2019: e.T65892925A67528106.

White L, Pryce D, Wilkins VL and Dutton A-J. (2019 b) Hogna cinica. The IUCN Red List of Threatened Species 2019: e.T65894025A67528113.

White L, Pryce D, Wilkins VL and Dutton A-J. (2019 c) Hogna inexorabilis. The IUCN Red List of Threatened Species 2019: e.T65894023A67528124.

White L, Pryce D, Wilkins VL and Dutton A-J. (2019 d) Hogna ligata. The IUCN Red List of Threatened Species 2019: e.T65894021A67528130.

White L, Pryce D, Wilkins VL and Dutton A-J. (2019 e) Hogna nefasta. The IUCN Red List of Threatened Species 2019: e.T65894027A67528136.

White L, Pryce D, Wilkins VL and Dutton A-J. (2019 f) Lycosa elysae. The IUCN Red List of Threatened Species 2019: e.T66182333A67528142.
White L, Pryce D, Wilkins VL and Dutton A-J. (2019 g) Lycosa ringens. The IUCN Red List of Threatened Species 2019: e.T66182359A67528149.

Wilder SM and Rypstra AL. (2008) Prior encounters with the opposite sex affect male and female mating behavior in a wolf spider (Araneae, Lycosidae). Behav Ecol Sociobiol. 62: 1813-1820.

World Conservation Monitoring Centre. (1996 a) Adelocosa anops. The IUCN Red List of Threatened Species 1996: e.T513A13058776.

World Conservation Monitoring Centre. (1996 b) Pardosa diuturna. The IUCN Red List of Threatened Species 1996: e.T16219A5555835.

World Conservation Monitoring Centre. (1996 c) Sosippus placidus. The IUCN Red List of Threatened Species 1996: e.T20421A9196826.

WSC. (2021) World Spider Catalog. Version 22.0. Natural History Museum Bern, online at http://wsc.nmbe.ch, accessed on March 31, 2021.

Yadav A and Kumar D. (2019) Diversity and distribution of spider species in different habitats of ChampanerPavagadh Archaeological Park, a world heritage site of Gujarat. Int J Sci Res Rev. 8: 85-95.

Yadav A, Solanki R, Siliwal M and Kumar D. (2017) Spiders of Gujarat: a preliminary checklist. J Threatened Taxa 9:10697-10716.

Yadav M, Goswami Tamil Nadu and Anil Ray SN. (2016) Species composition of spider-fauna in paddy ecosystem throughout the cropping period at Sabour, Bihar, India. Ecol Env Conserv. 22: 719-722.

Zehethofer K and Sturmbauer C. (1998) Phylogenetic relationships of Central European wolf spiders (Araneae: lycosidae) inferred from 12S ribosomal DNA sequences. Mol Phylogenet Evol. 10: 391-398. 